\title{
Appendices for: John Stuart Webb, FREng, and Applied Geochemistry at the Imperial College of Science and Technology, London
}

\author{
Richard J. Howarth \\ Department of Earth Sciences, University College London, Gower Street, London, WC1E 6BT, United Kingdom \\ (e-mail:r.bowarth@ucl.ac.uk)
}

A complete list of all GPRC/AGRG publications, plus the few AGRG Technical Communications not concerned with analytical methods, is given in Appendix 1; of Technical Communications on analytical methods in Appendix 2; and of GPRC/AGRG theses in Appendix 3.

\section{Appendix 1. Bibliography of GPRC/AGRG publications 1950-1988}

Abrahams, P. \& Thornton, I. 1987. Distribution and extent of land contaminated by arsenic and associated metals in the mining regions of southwest England. Transactions of the Institution of Mining and Metallurgy, London, B96, 1-8.

Alderton, D.M.H., Thompson, M., Rankin, A.H. \& Chryssoulis, S.L. 1982. Developments in the ICP-linked decrepitation technique for the analysis of fluid inclusions in quartz. Chemical Geology, 37, 203-213.

Alloway, B.J. 1973. Copper and molybdenum in swayback pastures. Journal of Agricultural Science, Cambridge, 80, 521-524.

Alloway, B.J. 1976. Field studies on magnesium, copper and zinc nutrition of maize. Journal of Agricultural Science, 86, 93-101.

Alloway, B.J. 1977. Trace elements in soils. In: King, S.J. (ed.) Soils in Cheshire, Part III, Sheet SJ45E/55W, Burwardsley. Report R43. Soil Survey of England and Wales, Harpenden, 119-126.

Alloway, B.J. 1978. Selected trace elements in soils on the Cheshire plain. In: Furness, R.R., Soils of Cheshire. Soil Survey Bulletin no. 6. Soil Survey of England and Wales, Rothampstead Experimental Station, Harpenden, 208-215.

Alloway, B.J. \& Davies, B.E. 1971. Heavy metal content of plants growing on soils contaminated by lead mining. Journal of Agricultural Science, 76, 321-323.

Alloway, B.J. \& Thornton, I. 1972. Studies of Welsh soils related to the agricultural interpretation of geochemical reconnaissance data. In: MUNRO, J.J.M. (ed.) Current research on Welsh soils. Welsh Soils Discussion Group Report no. 13. Welsh Plant Breeding Station, Aberystwyth. 161-181.

Alloway, B.J., Thornton, I., Smart, G.A., Sherlock, J.C. \& Quinn, M.J. 1988. The Shipham Report. An investigation into cadmium contamination and its implications for human health. Metal availability. Science of the Total Environment, 75, 41-69.

Anon. [Howarth, R.J.]. 1970. Computer programmes and subroutines available. Technical Communication, 57. Geochemical Prospecting Research Centre, Imperial College of Science and Technology, London.

Anon. [Howarth, R.J.]. 1973. Nonlinear mapping algorithm. Technical Communication, 58.Geochemical Prospecting Research Centre, Imperial College of Science and Technology, London.

Aplin, A.C. \& Cronan, D.S. 1985a. Ferromanganese oxide deposits from the Central Pacific Ocean. I. Encrustations from the Line Islands Archipelago. Geochimica et Cosmochemica Acta, 49, 427-436.

Aplin, A.C. \& Cronan, D.S. 1985b. Ferromanganese oxide deposits from the Central Pacific Ocean. II. Nodules and associated sediments. Geocbimica et Cosmochemica Acta, 49, 437-451.

Arias, J.A., Hale, M. \& WebB, J.S. 1979. Vapour dispersion of mercury and radon at Cachinal, Northern Chile. Revista Geologica de Chile, 8, 2-12.

Arias, J.A., Lovell, J.S. \& HaLe, M. 1982. Development and application of vapour geochemistry techniques to mineral exploration in overburden covered areas of northern Chile. Revista Geologica de Chile, 16, 23-80.

Armour-Brown, A. \& Nichol, I. 1970. Regional geochemical reconnaissance and the location of metallogenic provinces. Economic Geology, 65, 312-330.

Arnold, L., Van Dorst, S. \& Thornton, I. 1988. Factors influencing selenium uptake by some grass and clover species. In: Thornton, I. (ed.) Environmental Geochemistry and Health. Proceedings of the Second International
Symposium, held at the Royal Society, London, 22-24 April 1987. Environmental geochemistry and health monograph series. Science Reviews Limited (CRC Press), London. 183-188.

Arnórsson, S. 1970a. Underground temperatures in hydrothermal areas in Iceland as deduced from the silica content of the thermal water. United Nations Symposium on the Development and Utilisation of Geothermal Resource, Pisa. Geothermics [special issue], 2, 536-541.

Arnórsson, S. 1970b. The distribution of some trace elements in thermal waters in Iceland. In: United Nations Symposium on the Development and Utilisation of Geothermal Resource, Pisa. Geothermics [special issue], 2, 542-546.

Arnórsson, S. 1970c. Geochemical studies of thermal waters in the Southern Lowlands of Iceland. In: United Nations Symposium on the Development and Utilisation of Geothermal Resource, Pisa. Geothermics [special issue], 2, 547-552.

Arnórsson, S., Hawkes, H.E. \& Tooms, J.S. 1967. Present-day formation of pyrite in hot springs in Iceland. Transactions of the Institution of Mining and Metallurgy, B76, 115-117.

Aston, S.R. \& Chester, R. 1973. The influence of suspended particles on the precipitation of iron in natural waters. Estuarine and Coastal Marine Science, 1 , 225-231.

Aston, S.R., Bruty, D., Chester, R. \& Padgham, R.C. 1973. Mercury in lake sediments: a possible indicator of technological growth. Nature, London, 241, 450-451.

Aston, S.R. \& Thornton, I. 1975. The application of regional geochemical reconnaissance surveys in the assessment of water quality and estuarine pollution. Water Research, 9, 189-195.

Aston, S.R. \& Thornton, I. 1977. Regional geochemical data in relation to seasonal variations in water quality. Science of the Total Environment, 7, 247-260.

Aston, S.R., Thornton, I., Webb, J.S., Purves, J.B. \& Milford, B.L. 1974. Stream sediment composition: an aid to water quality measurement. Water, Air \& Soil Pollution, 3, 321-325.

Aston, S.R., Thornton, I., Webb, J.S., Milford, B.L. \& Purves, J.B. 1975. Arsenic in stream sediments and waters of South-west England. The Science of the Total Environment, 4, 347-358.

Barltrop, D., Strehlow, C.D., Thornton, I. \& Webb, J.S. 1974. Significance of high soil lead concentrations for childhood lead burdens. Environmental Health Perspectives, 7, 75-82.

Barltrop, D., Strehlow, C.D., Thornton, I. \& Webb, J.S. 1975. Absorption of lead from dust and soil. Postgraduate Medical Journal, 51, 801-804.

Bignell, R.D. 1975. Timing, distribution and origin of submarine mineralization in the Red Sea. Transactions of the Institution of Mining and Metallurgy, London, B84, 1-6.

Bignell, R.D., Cronan, D.S. \& Tooms, J.S. 1976a. Red Sea metalliferous brine precipitates. Transactions of the Geological Association of Canada, Special paper, 14, 148-184.

Bignell, R.D., Cronan, D.S. \& Tooms, J.S. 1976b. Metal dispersion in the Red Sea as an aid to marine geochemical exploration. Transactions of the Institution of Mining and Metallurgy, London, B85, 274-278.

Bignell, R.D., Tooms, J.S., Cronan, D.S. \& Horowitz, A. 1974. An additional location of metalliferous sediments in the Red Sea. Nature, London, 248, 127-128.

Boyden, C.R. 1973. Accumulation of heavy metals by shellfish. Proceedings of the Shellfish Association of Great Britain, 4th Annual Shellfish Conference. Shellfish Association of Great Britain, London, 38-48.

Boyden, C.R. 1974. Trace element content and body size in molluscs. Nature, London, 251, 311-314.

Boyden, C.R. 1975. Distribution of some trace metals in Poole Harbour, Dorset. Marine Pollution Bulletin, 6, 180-187.

Boyden, C.R. 1977. Effect of size upon metal content of shellfish. Journal of the Marine Biological Association of the United Kingdom, 57, 675-714. 
Boyden, C.R., Aston, S.R. \& Thornton, I. 1979. Tidal and seasonal variations of trace elements in two Cornish estuaries. Estuarine and Coastal Marine Science, 9, 303-317.

Boyden, C.R. \& Romeril, M.G. 1974. A trace metal problem in pond oyster culture. Marine Pollution Bulletin, 5, 74-78.

Boyden, C.R., Watling, H. \& Thornton, I. 1975. Effect of zinc on the settlement of the oyster Crassostrea gigas. Marine Biology, 31, 227-234.

Boyle, D.R. \& Troup, A.G. 1975. Copper-molybdenum porphry mineralization in central British Columbia, Canada. In: Jones, M.J. (ed.) Prospecting in Areas of Glacial Terrain. Institution of Mining and Metallurgy, London, 6-15.

Bradshaw, P.M.D. 1967. Distribution of selected elements in feldspar, biotite and muscovite from British granites in relation to mineralization. Transactions of the Institution of Mining and Metallurgy, B76, 137-148.

Bradshaw, P.M.D. \& Köksoy, M. 1968. Primary dispersion of mercury from cinnabar and stibnite deposits, W. Turkey. Proceedings of the XXIII International Geological Congress, Prague, 7, 341-335.

Brebner, J., Thornton, I., McDonald, P. \& Suttle, N.F. 1985. The release of trace elements from soils under conditions of simulated rumenal and abomassal digestion. In: Mills, C.F., Bremner, I. \& Chesters, J.K. (eds) TEMA 5, Proceedings of the 5 th International Symposium on Trace Elements in Man and Animals. Commonwealth Agricultural Bureau, Farnham Royal, Slough, $850-852$.

Brebner, J., Suttle, N.F. \& Thornton, I. 1987. Assessing the availability of ingested soil cobalt for the synthesis of Vitamin B12 in the bovine rumen. Procedings of the Nutrition Society, 46, 766A.

Brereton, A., Lord, H., Thornton, I. \& Webb, J.S. 1973. Effect of zinc on growth and development of larvae of the Pacific oyster Crassostrea gigas. Marine Biology, 19, 96-101.

Brierley, C.L. \& Thornton, I. 1979a. Preliminary observations on the effect of heavy metals from mining and smelting on nitrogen-fixing bacteria in some British soils. Minerals Environment, 1, 112-119.

Brierley, C.L. \& Thornton, I. 1979b. Preliminary observations on the effect of heavy metals from mining and smelting on nitrogen-fixing bacteria in some British soils. Environmental Geochemistry and Health, 1, 161-168.

Bruty, D., Chester, R. \& Aston, S.R. 1973. Trace elements in Ancient Atlantic deep-sea sediments. Nature, London, 245, 73-74.

Cannon, H.L., Connally, C.G., Epstein, J.B., Parker, J.G., Thornton, I. \& WIXoN, B.G. 1978. Rock: The geological sources of most trace elements. Geochemistry and the environment. Vol. 3. Distribution of trace elements related to the occurrence of certain cancers, cardiovascular diseases and urolithiasis. National Academy of Sciences, Washington, DC, 17-31.

Carmichael, I.S.E. \& McDonald, A.J. 1961a. The colorimetric and polarographic determination of some trace elements in standard rocks G-1 and W-1. Geochimica et Cosmochimica Acta, 22, 87-93.

Carmichael, I.S.E. \& McDonald, A.J. 1961b. Geochemistry of some natural and acid glasses from the North Atlantic Tertiary Volcanic province. Geochimica et Cosmochimica Acta, 25, 189-222.

Castillo-Muñoz, R. \& Howarth, R.J. 1976. Application of the empirical discriminant function to regional geochemical data from the United Kingdom. Bulletin of the Geological Society of America, 87, 1567-1581.

Colbourn, P., Alloway, B.J. \& Thornton, I. 1975. Arsenic and heavy metals in soils associated with regional geochemical anomalies in southwest England. Science of the Total Environment, 4, 359-363.

Colbourn, P. \& Thornton, I. 1978. Lead pollution in agricultural soils in the southern Peak District. Journal of Soil Science, 29, 513-526.

Cole, M.M., Provan, D.M.J. \& Tooms, J.S. 1968. Geobotany, biogeochemistry and geochemistry in mineral exploration in the Bulman-Waimuna Springs area, Northern Territory, Australia. Transactions of the Institution of Mining and Metallurgy, B77, 81-104 [Discussion, B78, 98-100].

Colley, N., Cronan, D.S. \& Moorby, S.A. 1979. Some geochemical and mineralogical studies on newly collected ferromanganese oxide deposits from the north-western Indian Ocean. In: LALOU, C. (ed.) Sur la genèse des nodules de manganese. Gif sur Yvette, France. Colloques Internationaux du Centre Nationale de la Recherche Scientifique, 289, 13-21.

Coope, J.A. \& WebB, J.S. 1963. Copper in stream sediments near disseminated copper mineralisation, Cebu, Philippine Republic. Transactions of the Institution of Mining and Metallurgy, 72, 397-406 [Discussion, 72, 669-670; Authors' reply to discussion: 72, 761-763].

Cooper, R.A., Woolf, D.L. \& Tooms, J.S. 1964. A geochemical reconnaissance survey of part of the Labuk Valley, Sabah. Borneo Region, Malaysia Geological Survey Annual Report for 1964. Government Printing Office, Kuching, Sarawak. 176-185.

Coward, N. \& Cronan, D.S. 1987. A statistical evaluation of geochemical data in regard to bedrock and placer mineral exploration in the S.W. Pacific. Marine Mining, 6, 205-221.
Craven, C.A.U. 1954. Statistical estimation of the accuracy of assaying. Transactions of the Institution of Mining and Metallurgy, 63, 551-563.

Cronan, D.S. 1973a. Basal ferruginous sediments cored during Leg 16, Deep Sea Drilling Project. In: Van Andel, T.H., Heath, G.R., Bennett, R.H., Bukry, J.D., Charleston, S., Cronan, D.S., Dinkelman, M.G., Kaneps, A.G., Rodolfo, K.S. \& Yeats, R.S. (eds) Initial Reports of the Deep Sea Drilling Project, 16. U.S. Government Printing Office, Washington, 601-604.

Cronan, D.S. 1973b. Manganese nodules in sediments cored during Leg 16, Deep Sea Drilling Project. In: Van Andel, T.H., Heath, G.R., Bennett, R.H., Bukry, J.D., Charleston, S., Cronan, D.S., Dinkelman, M.G., Kaneps, A.G., Rodolfo, K.S. \& Yeats, R.S. (eds) Initial Reports of the Deep Sea Drilling Project, 16. U.S. Government Printing Office, Washington, 605-608.

Cronan, D.S. 1974. Authigenic minerals in deep-sea sediments. In: Goldberg, E.D. (ed.) Marine chemistry. The Sea: ideas and observations on progress in the study of the seas, 5. Wiley-Interscience, New York, 491-525.

Cronan, D.S. 1975 a. Zinc in marine manganese nodules. Transactions of the Institution of Mining and Metallurgy, London, B84, 30-32.

Cronan, D.S. 1975b. Manganese nodules and other ferromanganese oxide deposits from the Atlantic Ocean. Journal of Geophysical Research, 80, 3831-3837.

Cronan, D.S. 1975c. Geological and geochemical factors determining the variability of marine manganese nodules. Oceanology International 75: Conference Papers, 16/21 March 1975, Brighton, England. BPS Exhibitions, London, 118-120.

Cronan, D.S. 1976a. Implications of metal dispersion from submarine hydrothermal systems for mineral exploration on mid-ocean ridges and in island arcs. Nature, London, 262, 567-569.

Cronan, D.S. 1976b. Riches of the ocean floor. Spectrum, 137, 10-12.

Cronan, D.S. 1976c. Mineral exploration in the Indian Ocean. Ocean Industry, 11, 86-87.

Cronan, D.S. 1976d. Manganese nodules and other ferromanganese oxide deposits. In: Riley, J.P. \& Chester, R. (eds) Chemical Oceanography, 5. Academic Press, London. 217-263.

Cronan, D.S. 1976e. Basal metalliferous sediments from the eastern Pacific. Geological Society of America Bulletin, 87, 928-934.

Cronan, D.S. $1977 a$. Deep sea manganese nodules: Distribution and geochemistry. In: Glasby, G.P. (ed.) Marine manganese deposits. Elsevier, Amsterdam, 11-44.

Cronan, D.S. 1977b. RRS Shackleton in the Indian and south Atlantic Oceans [Conference report]. Journal of the Geological Society, London, 134, 77-80.

Cronan, D.S. 1977c. Geochemical investigations on sediments from the Mid-Atlantic Ridge, Leg 37, Deep Sea Drilling Project. In: Melson, W., Aumento, F., Hall, J.M., Bourgault, H., Dmitriev, L, Fischer, J.F., Flower, M., Howe, R.C., Hyndman, R.D., Miles, G.A., Robinson, P.T. \& Wright, T.L. (eds) Initial Reports of the Deep Sea Drilling Project, 37. U.S. Government Printing Office, Washington, 631-632.

Cronan, D.S. $1977 d$. Metalliferous sediments and manganese nodules on the ocean floor. Chemistry and Industry, 14, 576-578.

Cronan, D.S. 1978a. Recent advances in geochemical exploration for undersea mineral deposits. Transactions of the Institution of Mining and Metallurgy, London, A87, 143-146.

Cronan, D.S. 1978b. Manganese nodules, controversy upon controversy. Endeavour, 2, 80-84.

Cronan, D.S. 1978c. Geochemistry of oceanic ferromanganese deposits: Discussion. Philosophical Transactions of the Royal Society, London, A290, 72-73.

Cronan, D.S. 1978d. Geochemical exploration for submarine metalliferous deposits in the southwest Pacific [Abstract]. AAPG Bulletin, 62, 1213.

Cronan, D.S. 1979a. Metallogenesis at oceanic spreading centres. Journal of the Geological Society, London, 176, 621-626.

Cronan, D.S. 1979b. Geochemical methods for prospecting for manganese nodules. metalliferous muds. Ressources minérales sous-marines [Offshore mineral deposits]: Orleans, France, 23-27 Octobre 1978. Comptes rendus. Documents du Bureau de recherches géologiques et minières, Orléans, 7, 393-402.

Cronan, D.S. 1980a. Underwater Minerals. Academic Press, London.

Cronan, D.S. 1980b. Marine geology and oceanography of the Pacific manganese nodule province. Mineralogical Magazine, 43, 956-957.

Cronan, D.S. 1980c. Manganese nodules: Research data and methods of investigation. Mineralogical Magazine, 43, 957.

Cronan, D.S. 1980d. Metallogenesis at ocean spreading centres. Journal of the Geological Society, London, 137, 369-371.

Cronan, D.S. 1981. Local variability in the grade and abundance of manganese nodules: implications for manganese nodule mine site evaluation. Proceedings of the Engineering Committee on Oceanic Resources [ECOR] Symposium London, 7-9 April 1971. Engineering Committee on Oceanic Resources, London. 
Cronan, D.S. 1983a. Metalliferous sediments in the CCOP/SOPAC region of the Southwest Pacific: with particular reference to geochemical exploration for the deposits. CCOP/SOPAC Suva, Fiji. Technical Bulletin, 4.

Cronan, D.S. 1983b. Criteria for the recognition of areas of potentially economic manganese nodules and encrustations in the CCOP/SOPAC region of the central and southwestern tropical Pacific. United Nations Development Programme. Economic and Social Commission for Asia and the Pacific. Technical Report, 30.

Cronan, D.S. 1984. Criteria for the recognition of areas of potentially economic manganese nodules and encrustations in the CCOP/SOPAC region of the central and southwestern tropical Pacific. South Pacific Marine Geological Notes, 3, 1-17.

Cronan, D.S. 1985. Marine mineral resources. Geology Today, 1, 15-19.

Cronan, D.S. (ed.) 1986a. Sedimentation and Mineral Deposits in the Southwest Pacific Ocean. Academic Press, London and Orlando, FL.

Cronan, D.S. 1986b. Regional geochemistry of sediments from the southwestern Pacific. In: Cronan, D.S. (ed.) Sedimentation and Mineral Deposits in the Southwest Pacific Ocean. Academic Press, London and Orlando, FL, 117-146.

Cronan, D.S. 1986c. Geochemical exploration for deep sea mineral deposits. In: Thornton, I. \& Howarth, R.J. (eds) Applied Geochemistry in the 1980s. Graham and Trotman, London, 241-259.

Cronan, D.S. 1986d. Review of the development of marine geochemical exploration procedures for sea floor mineral deposits in the southwest Pacific Ocean. In: Nesbitt, R. \& Nichol, I. (eds) Geology in the Real World - the Kingsley Dunham Volume. Institution of Mining and Metallurgy, London, 65-74.

Cronan, D.S. 1986e. Potentially economic manganese nodule deposits in Western Equatorial Pacific [Abstract]. AAPG Bulletin, 70, 918.

Cronan, D.S. 1987. Controls on the nature and distribution of manganese nodules in the western equatorial Pacific. In: Teleki, P.G. (ed.) Proceedings of the NATO Advanced research workshop on marine minerals: resources assessment strategies (1985). NATO ASI series. Series C, Mathematical and Physical Sciences, 194, 177-188.

Cronan, D.S., Damiani, V.V., Kinsman, D.J.J. \& Thiede, J. 1974. Sediments from the Gulf of Aden and Western Indian Ocean. In: Fisher, R.L., Bunce, E.T., Cernock, P.J., Clegg, D.C., Cronan, D.S., Damiani, V.V., Dmitriev, L.V., Kinsman, D.J.J., Roth, P.H., Thiede, J. \& Vincent, E. (eds) Initial Reports of the Deep Sea Drilling Project, 24. U.S. Government Printing Office, Washington, 1047-1110.

Cronan, D.S. \& Garrett, D.E. 1973. Distribution of elements in metalliferous Pacific sediments collected during the Deep Sea Drilling Project. Nature, London, 242, 88-89.

Cronan, D.S., Glasby, G.P., Halunen, J., Cooper, J., Collen, J.D., Knedler, K., Johnson, J., Landmesser, C. \& Wingfield, R. 1981. Sediments from the Braemar Ridge and Yasawa Trough, northwest of Fiji. South Pacific Marine Geological Notes, 2, 25-35.

Cronan, D.S., Glasby, G.P., Moorby, S.A., Thompson, J., Knedler, K. \& McDougall, J.C. 1982. A submarine hydrothermal manganese deposit from the south-west Pacific island arc. Nature, London, 298, 456-458.

Cronan, D.S. \& Hodkinson, R. 1994. Element supply to surface manganese nodules along the Aitutaki-Jarvis Transect, South Pacific. Journal of the Geological Society, London, 151, 391-401.

Cronan, D.S., Hodkinson, R., Moorby, S.A., Glasby, G.P., Knedler, K. \& Thomson, J. 1984. Hydrothermal and volcaniclastic sedimentation in the Tonga-Kermadec Ridge and in its adjacent marginal basins. In: KoKelaAr, B.P. \& Howells, M.F. (eds) Marginal Basin Geology. Geological Society, London, Special Publications, 16, 137-149.

Cronan, D.S., Hodkinson, R., Harkness, D.D., Moorby, S.A. \& Glasby, G.P. 1986. Accumulation rates of hydrothermal metalliferous sediments in the Lau Basin, S.W. Pacific. Geo-Marine Letters, 6, 51-56.

Cronan, D.S., Kunzendorf, H., Archer, A.A., Ergun, M., Harris, D.P., Haynes, B.W., Manginia, A., Siapno, W.D. \& Von Stackelberg, U. 1987. Report of the Working Group on manganese nodules and crusts. In: Teleki, P.G. (ed.) Proceedings of the NATO Advanced research workshop on marine minerals: resources assessment strategies (1985). NATO ASI series. Series C, Mathematical and Physical Sciences, 194, 21-27.

Cronan, D.S. \& Moorby, S.A. 1976. Preliminary results of renewed investigations on manganese nodules and encrustations in the Indian Ocean. In: Glasby, G.P. \& Katz, H.R. (eds). Papers presented at the I.D.O.E. workshop, Suva, Fiji, 1-6 September 1975. United Nations Economic and Social Commission for Asia and the Pacific, Committee for Co-ordination of Joint Prospecting for Mineral Resources in South Pacific Offshore Areas. Technical Bulletin, 2, 118-123.
Cronan, D.S. \& Moorby, S.A. 1980. Manganese nodules and other ferromanganese oxide deposits from the Indian Ocean. Journal of the Geological Society, London, 138, 527-539.

Cronan, D.S. \& Moorby, S.A. 1981. Manganese nodules and other ferromanganese oxide deposits from the Indian Ocean. Journal of the Geological Society, London, 138, 527-539.

Cronan, D.S., Rona, P.A. \& Shearme, S. 1979. Metal enrichments in sediments from the TAG Hydrothermal Field. Marine Mining, 2, 79-89.

Cronan, D.S., Smith, P.A. \& Bignell, R.D. 1977. Modern submarine bydrothermal mineralization: Examples from Santorini and the Red Sea. Geological Society, London, Special Publications, 7, 80.

Cronan, D.S. \& Thompson, B. 1978. Regional geochemical reconnaissance survey for metalliferous sediments in the southwestern Pacific - a preliminary note. Transactions of the Institution of Mining and Metallurgy, London, B87, 87-90.

Cronan, D.S. \& Tooms, J.S. $1967 a$. Sub-surface concentrations of manganese nodules in Pacific sediments. Deep-Sea Research, 14, 117-119.

Cronan, D.S. \& Tooms, J.S. 1967b. Geochemistry of manganese nodules from the N.W. Indian Ocean. Deep-Sea Research, 14, 239-249.

Cronan, D.S. \& Tooms, J.S. 1968. A microscopic and electron probe investigation of manganese nodules from the northwest Indian Ocean. Deep-Sea Research, 15, 215-223.

Cronan, D.S. \& Tooms, J.S. 1969. The geochemistry of manganese nodules and associated pelagic deposits from the Pacific and Indian Oceans. Deep Sea Research, 16, 335-359.

Cronan, D.S. \& Varnavas, S.P. 1981. Hydrothermal and dissolution related geochemical variations in sediments from an East Pacific Rise Fracture Zone at $9^{\circ} \mathrm{S}$. Colloque 4. Geology of the oceans. 26th International Geological Congress. Oceanologica Acta, SP, 47-58.

Culbard, E.B. \& Johnson, L.R. 1984. An assessment of arsenic in house dust and garden soils from southwest England and their implications for human health. Proceedings of the International Conference on Environement Contamination, Imperial College, London. CEP Consultants, Edinburgh, 432-437.

Culbard, E.B., Moorcroft, S., Watt, J., Thornton, I. \& Thomas, J.F.A. 1983a. Nationwide reconnaissance survey of metals in urban dusts and soils. Minerals and the Environment, 5, 82-84.

Culbard, E.B., Thornton, I., Watt, J., Moorcroft, S. \& Brooks, K. 1983 b. Sources and distribution of lead and cadmium in United Kingdom dusts and soils. Proceedings of the Conference on Heary Metals in the Environment, Heidelberg. CEP Consultants, Edinburgh, 1, 426-429.

Culbard, E.B., Thornton, I., Watt, J., Moorcroft, S., Brooks, K. \& Thompson, M. 1983c. Metal contamination of dusts and soils in urban and rural households in the United Kingdom 2. A nationwide reconnaissance survey of the United Kingdom to determine metal concentrations in urban dusts and soils In: Hemphill, D.D. (ed.) Trace Substances in Environmental Health XVII. University of Missouri, Columbia, MS, 236-241.

Culbard, E.B., Johnson, D.L.J. \& Watt, J. 1986. Microscopy based techniques used in the apportionment of lead sources in household dust. In: Thornton, I. (ed.) Proceedings of the 1 st International Symposium on Geochemistry and Health. Science Reviews, Northwood, United Kingdom, 250-254.

Culbard, E., Thornton, I., Watt, J., Wheatley, M., Moorcroft, S. \& Thompson, M. 1988. Metal contamination in British urban dusts and soils. Journal of Environmental Quality, 17, 226-234.

Daniel, M.J. \& Boyden, C.R. 1975. Diurnal variations in physico-chemical conditions within intertidal rockpools. Field Studies, 4, 161-176.

Darracott, A. \& Watling, H. 1975. The use of molluscs to monitor cadmium levels in estuaries and coastal marine environments. Transactions of the Royal Society of South Africa, 41, 325-335.

Davies, D.J.A. \& Thornton, I. 1987. The influence of house age on lead levels in dusts and soils in Brighton, England. Environmental Geochemistry and Health, 9, 65-67.

Davies, D.J.A., Thornton, I., Watt, J. \& Culbard, E.B. 1987 . Lead levels in and around the homes of inner city children. In: Thornton, I. \& Culbard, E.B. (eds) Lead in the Home Environment, Science Reviews, London, 105-112.

Davies, D.J., Thornton, I., Watt, J.M., Culbard, E.B., Harvey, P.G., Delves, H.T., Sherlock, J.C., Smart, G.A., Thomas, J.F.A. \& Quinn, M.J. 1987b. Lead intake and blood lead in two year old U.K. urban children. Science of the Total Environment, 90, 13-29.

Davies, D.J.A., Thornton, I., Watt, J.M., Culbard, E.B., Harvey, P.G., Delves, H.T., Sherlock, J.C., Smart, G.A., Thomas, J.F.A. \& Quinn, M.J. 1987c. Relationship between blood leadlead intake in two year old urban children in the UK. Proceedings of the Sixth International Conference on Heavy Metals in the Environment. New Orleans, Louisiana, September 15-18, 1987. CEP Consultants, Edinburgh. 2, 203-205. 
Davies, D.J.A. \& WatT, J. 1986. An assessment of the quantity and significance of lead on the hands of inner city children in the United Kingdom. In: Hemphill, D.D. (ed.) Trace Substances in Environmental Health XX. University of Missouri, Columbia, MS, 333-344.

Davies, D.J., Watt, J.M. \& Thornton, I. 1987a. Lead levels in Birmingham dusts and soils. Science of the Total Environment, 67, 177-185.

Davies, D.J.A., Watt, J.M. \& Thornton, I. 1987b. Air lead concentrations in Birmingham, England - a comparison between lead levels inside and outside inner-city homes. Environmental Geochemistry and Health, 9, 3-7.

Davies, D.J.A., Watt, J.M., Thornton, I. \& Quinn, M.J. 1987c. Indoor and outdoor air lead concentrations - implications for the health of young children. In: Lindierg, S.C. \& Hutchinson, T.C. (eds) Proceedings of the Sixth International Conference on Heavy Metals in the Environment, New Orleans, Louisiana, September 15-18, 1987. CEP Consultants, Edninburgh, 2, 292-294.

Debnam, A.H. \& Webb, J.S. 1960. Some geochemical anomalies in soil and stream sediment related to beryl pegmatites in Rhodesia and Uganda. Transactions of the Institution of Mining and Metallurgy, 69, 329-344 [Discussion, 69, 637-641]

Dunlop, A.C. \& Meyer, W.T. 1973. Influence of late Miocene-Pliocene submergence on regional distribution of tin in stream sediments, southwest England. Transactions of the Institution of Mining and Metallurgy, London, B82, 62-64.

EARLE, S.A.M. 1978. Spatial presentation of data from regional geochemical stream surveys. Transactions of the Institution of Mining and Metallurgy, London, B87, 61-65.

Elderfield, H., Thornton, I. \& Webb, J.S. 1971. Heavy metals and oyster culture in Wales. Marine Pollution Bulletin, 2, 44-47.

Ellis, A.J., Tooms, J.S., WebB, J.S. \& Bicknell, J.V. 1967. Application of solution experiments in geochemical prospecting. Transactions of the Institution of Mining and Metallurgy, B76, 25-39 [Discussion, B76, 216-217; Authors' reply to discussion: B77, 136].

El Shazly, E.M., Webb, J.S. \& Williams, D. 1957. Trace elements in sphalerite and associated minerals from the British Isles. Transactions of the Institution of Mining and Metallurgy, 66, 241-271 [Discussion, 66, 478-490. Authors' reply to discussion, 67, 186-191].

Exon, N.F. \& Cronan, D.S. 1983. Hydrothermal iron deposits and associated sediments from submarine volcanoes off Vanatu, Southwest Pacific. Marine Geology, 52, M43-M52.

Fitch, F.H. \& Webb, J.S. 1958. Copper deposits in the Sandarkan Area and parts of the Kinabatangan and Labuk Valleys, North Borneo. In: Fiтch, F.H. (ed.) The Geology and Mineral Resources of the Sandarkan Area, North Borneo. Memoir 9, Geological Survey Department, British Territories in Borneo. Government Printing Office, Kuchung, Sarawak, 115-152.

GarRetT, R.G. \& Nichol, I. 1967. Regional geochemical reconnaissance in eastern Sierra Leone. Transactions of the Institution of Mining and Metallurgy, B76, 97-112 [Discussion, B77, 78-79].

Gladwell, D.R. \& Hale, M. 1987. Multifractional analysis in geochemical exploration for tin mineralization. Journal of Geochemical Exploration, 29, 1-3.

Gladwell, D., Thompson, M. \& Wood, S.J. 1981. The determination of cassiterite tin in soils and sediments by an atomic absorption - volatile hydride method. Journal of Geochemical Exploration, 16, 41-48.

Glasby, G.P. 1981. Manganese nodule studies in the Southwest Pacific 1975-1980: a review. South Pacific Marine Geological Notes, 2, 37-46.

Glasby, G.P., Tooms, J.S. \& Cann, J.R. 1971. The geochemistry of manganese encrustations from the Gulf of Aden. Deep-Sea Research, 18, 11791187.

Glasby, G.P., Tooms, J.S. \& Howarth, R.J. 1974. Geochemistry of manganese concretions from the northwest Indian Ocean. New Zealand Journal of Science, 17, 387-407.

Govetr, G.J.S. 1960. Geochemical prospecting for copper in northern Rhodesia: Variation in the concentration of secondarily dispersed copper in soils and stream sediments due to differences in physical-chemical properties of the sample materials. Report of the 21st Session International Geological Congress, Norden, 2, 44-56.

Govett, G.J.S. 1961. Seasonal variation in the copper concentration in drainage systems in Northern Rhodesia. Transactions of the Institution of Mining and Metallurgy, 70, 177-189.

Gregory, P. \& Tooms, J.S. 1969. Geochemical prospecting for kimberlites. Quarterly of the Colorado School of Mines, 64, 265-305.

Halcrow, W., Mackay, D.W. \& Thornton, I. 1973. The distribution of trace metals and fauna in the Firth of Clyde in realtion to the disposal of sewage sludge. Journal of the Marine Biological Association of the United Kingdom, 53, 721-739.

Hale, M. 1979. A regional geochemical atlas: techniques and applications. Royal School of Mines Journal, London, 78, 13-22.
Hale, M. 1981. Pathfinder applications of arsenic, antimony and bismuth in geochemical exploration. Journal of Geochemical Exploration, 15, 307-323.

Hale, M. \& Thompson, M. 1983. Laser ablation - inductively coupled plasma spectrometry for geochemical exploration. Transactions of the Institution of Mining and Metallurgy, London, B92, 23-27.

Hale, M., Thompson, M. \& Wheatley, M.R. 1984. Laser ablation of stream sediment pebble coatings for simultaneous multielement analysis in geochemical exploration. Journal of Geochemical Exploration, 21, 361-371.

Harden, G. \& Tooms, J.S. 1965. Efficiency of the potassium bisulphate fusion in geochemical analyses. Transactions of the Institution of Mining and Metallurgy, 74, 129-141 [Discussion, 75, 104].

Hawkes, H.E. \& Webb, J.S. 1962. Geochemistry in mineral exploration. Harper \& Row, New York, Hamish Hamilton, London.

Hawkes, H.E., Bloom, H., Riddell, J.E. \& Webb, J.S. 1960. Geochemical Reconnaissance in Eastern Canada. Report of the 20th International Geological Congress, Mexico City. 1956. Symposium on Geochemical Exploration, 3, 607621

Hazelhoff Roelfzema, B.H. \& Tooms, J.S. 1970. Dispersion of cassiterite in the marine sediments of western Mounts Bay, Cornwall. In: Fox, W. (ed.) A Second Technical Conference on Tin, Bangkok 1969. International Tin Council, London, 2, 491-516.

Hekinian, R., Rosendahl, B.R., Cronan, D.S., Dmitriev, Y., Fodor, R.V., Goll, R.M., Mohoffert, S., Humphries, S., Mattey, D.P., Natland, J., Petersen, N., Roggenthen, W., Schrader, E.L., Srivastava, R.K. \& Warren, N. 1978. Hydrothermal deposits and associated basement rocks from the Galapagos spreading centre. Oceanologica Acta, 1, 473-482.

Higgo, J.J.W., Rees, L.V.C. \& Cronan, D.S. 1983. Sorption of americium and neptunium by deep sea sediments. Radioactive Waste Management and the Nuclear Fuel Cycle, 4, 73-102.

Higgo, J.J.W., Rees, L.V.C. \& Cronan, D.S. 1985. Sorption of plutonium by deep-sea sediments. Radioactive Waste Management and the Nuclear Fuel Cycle, 6, 143-159.

Hodkinson, R., Cronan, D.S., Glasby, G.P. \& Moorby, S.A. 1986. Geochemistry of marine sediments from the Lau Basin, Havre Trough, and Tonga-Kermadec Ridge. New Zealand Journal of Geology and Geophysics, 29, 335-344.

Holman, R.H.C. 1956a. Geochemical prospecting studies in the Kilembe area, Uganda. Dispersion of copper in the drainage system. Technical Communication, 9. Geochemical Prospecting Research Centre, Imperial College of Science and Technology, London.

Holman, R.H.C. 1956b. A method for determining readily-soluble copper in soil and alluvium - Introducing white spirit for dithizone. Transactions of the Institution of Mining and Metallurgy, 66, 7-16.

Holman, R.H.C. \& WebB, J.S. 1957. Exploratory Geochemical Soil Survey at Ruhiza Ferberite Mine, Uganda. In: De Wet, J.P. (ed.) Methods and Case Histories in Mining Geophysics. General Committee of the Sixth Commonwealth mining and Metallurgical Congress. Mercury Press, Montreal, 353-357.

Holmes, R. \& Tooms, J.S. 1973. Dispersion from a submarine exhalative orebody. In: Jones, M.J. (ed.) Geochemical Exploration 1972. Proceedings of the Fourth International Geochemical Exploration Symposium, held in London from 17 to 20 April, 1972. Institution of Mining and Metallurgy, London, 193-202.

Horder, M. \& Cronan, D.S. 1981. The geochemistry of some basal sediments from the western Indian Ocean. Oceanologica Acta, 4, 213-221.

Horder, M.F. \& Howarth, R.J. (eds). 1982. Computer Applications in Geology I \& II. Geological Society of London Miscellaneous Paper, 14.

Horowitz, A. 1974. The geochemistry of sediments from the northern Reykjanes Ridge and Iceland-Faroes Ridge. Marine Geology, 17, 103-122.

Horowitz, A. \& Cronan, D.S. 1976. The geochemistry of basal sediments from the north Atlantic Ocean. Marine Geology, 20, 205-228.

Howarth, R.J. 1971a. Fortran IV program for grey-level mapping of spatial data. Mathematical Geology, 3, 95-121 [Addendum: 4, 275-276].

Howarth, R.J. 1971b. An empirical discriminant method applied to sedimentary rock classification from major-element geochemistry. Mathematical Geology, 3, 51-60.

Howarth, R.J. 1971c. Empirical discriminant classification of regional stream-sediment geochemistry in Devon and east Cornwall. Transactions of the Institution of Mining and Metallurgy, B80, 142-149 [Discussion: B81, 116-119].

Howarth, R.J. 1972. Empirical discriminant classification of regional streamsediment geochemistry in Devon and east Cornwall [discussion]. Transactions of the Institution of Mining and Metallurgy, B81, 115-119

Howarth, R.J. 1973a. Preliminary assessment of a nonlinear mapping algorithm in a geological context. Mathematical Geology, 5, 39-57. 
HowarTH, R.J. 1973b. The pattern recognition problem in applied geochemistry. In: Jones, M.J. (ed.) Geochemical Exploration 1972. Institution of Mining and Metallurgy, London, 259-273.

HowarTh, R.J. 1973c. Monte Carlo simulation of matrix correlation effects. Analyst, London, 98, 777-781.

HowARTH, R.J. 1973d. FORTRAN IV programs for empirical discriminant classification of spatial data. Geocom Bulletin, 6 [Geocom Programs, 7], 1-31.

Howarth, R.J. 1974a. The impact of pattern recognition methodology in geochemistry. Proceedings of the Second International Conference on Pattern Recognition, Copenhagen, 411-412.

Howarti, R.J. 1974b. Data Processing for the Provisional Geochemical Atlas of Northern Ireland. Technical Communication, 61. Applied Geochemistry Research Group, Imperial College of Science and Technology, London.

Howarth, R.J. 1977a. Cartography in geochemical exploration. Science de la Terre, Serie Informatique Geologique, 9, 105-128.

Howarth, R.J. 1977b. Automatic generation of randomised sample submittal schemes for laboratory analysis. Computers \& Geosciences, 3, 327-334.

Howarth, R.J. 1977c. Approximate levels of significance for the $\cos \theta$ coefficient. Computers \& Geosciences, 3, 25-30.

Howarth, R.J. 1982. The Box-Cox lambda transform as a geological tool. [Abstract]. In: Horder, M.F. \& Howarth, R.J. (eds) Computer Applications in Geology I \& II. Geological Society of London, London, 88.

Howarth, R.J. (ed.) 1983a. Statistics and data analysis in geochemical prospecting. In: Govetr, G.J.S. (series ed.) Handbook of Exploration Geochemistry, 2. Elsevier, Amsterdam.

Howarth, R.J. 1983b. Mapping. In: Howarth, R.J. (ed.) Statistics and data analysis in geochemical prospecting. Elsevier, Amsterdam, 111-205.

Howarth, R.J. 1983c. Graphical aids for some statistical tests. In: Howarth, R.J. (ed.) Statistics and data analysis in geochemical prospecting. Elsevier, Amsterdam, 393-401.

Howarth, R.J. 1983d. A merge facility for files with missing records. Computers \& Geosciences, 9, 269-272.

Howarth, R.J. 1984. Statistical applications in geochemical prospecting: A survey of recent developments. Journal of Geochemical Exploration, 21, 41-61.

Howarth, R.J., Cronan, D.S. \& Glasby, G.P. 1977. Non-linear mapping of regional geochemical variability of manganese nodules in the Pacific Ocean. Transactions of the Institution of Mining and Metallurgy, London, B86, $4-8$.

Howarth, R.J. \& Earle, S.A.M. 1979. Application of a generalised power transform to geochemical data. Mathematical Geology, 11, 45-58.

Howarth, R.J. \& GarretT, R.G. 1986. The role of computing in applied geochemistry. In: Thornton, I. \& Hownrth, R.J. (eds) Applied Geochemistry in the 1980s. Graham \& Trotman, London, 163-184.

Howarth, R.J. \& Johnson, R.W. 1977. Multi-element trends of variation of the South Bismark Sea rocks as shown by the nonlinear mapping algorithm. In: Johnson, R.W. (ed.) Distribution and major-element chemistry of late Cainozoic volcanoes at the southern margin of the Bismark Sea, Papua New Guinea. Australian Bureau of Mineral Resources, Canberra, Report, 188, 162-170.

Howarth, R.J. \& КосH, G.S. 1986. Problems of using rock-volume data in predictive resource studies. Economic Geology, 81, 617-626.

Howarth, R.J., Koch, G.S., Chork, C.Y., Carpenter, R.H. \& Schuenemeyer, J.H. 1980. Statistical map analysis techniques applied to regional distribution of uranium in stream sediment samples from the southeastern United States for the National Uranium Resource Evaluation program. Mathematical Geology, 12, 339-366.

Howarth, R.J., Косh, G.S., Plant, J.A. \& Lowry, R.K. 1981. Identification of uraniferous granitoids in the USA using stream sediment geochemical data. Mineralogical Magazine, 44, 455-470.

Howarth, R.J. \& Leake, B.E. 1980. The role of data processing in the geological sciences. Science Progress, Oxford, 66, 295-329.

Howarth, R.J. \& Lim, A.L. 1969. An approach to program documentation. Computer Bulletin, 13, 291-295.

Howarth, R.J. \& Lowenstein, P.L. 1971. Sampling variability of streamsediments in broad-scale geochemical reconnaissance. Transactions of the Institution of Mining and Metallurgy, B80, 363-372 [Discussion: B81, 122123].

Howarth, R.J. \& Lowenstein, P.L. 1973a. Colour mapping by computer. Proceedings of the Computer Arts Society Meeting, University of Edinburgh, August 1973, 1-6.

Howarth, R.J. \& Lowenstein, P.L. 1973b. Digital processing of geochemical data with particular reference to new output methods. Proceedings of the Planning and Transport Research and Computation Summer Annual Meeting, University of Sussex. Planning and Transport Research and Computation, London, 1-12.
Howarth, R.J. \& Lowenstein, P.L. 1974. Data processing for the Provisional Geochemical Atlas of Northern Ireland. Technical Communication, 61. Geochemical Prospecting Research Centre, Imperial College of Science and Technology, London.

Howarth, R.J. \& Lowenstein, P.L. 1976. Three-component maps from lineprinter output. Transactions of the Institution of Mining and Metallurgy, B85, 234-237.

Howarth, R.J. \& Martin, L. 1979. Computer-based techniques in the compilation, mapping and interpretation of exploration geochemical data. In: Hood, P.J. (ed.) Geophysics and Geochemistry in the Search for Metallic Ores. Geological Survey of Canada, Ottawa, 545-574.

Howarth, R.J., Ruan, T. \& Hale, M. 1985. Numerical modelling experiments in vapour geochemistry. I: Method and Fortran program. Computers \& Geosciences, 11, 55-67.

Howarth, R.J. \& Sinding-Larsen, R. 1983. Multivariate analysis. In: Howarth, R.J. (ed.) Statistics and data analysis in geochemical prospecting. Elsevier, Amsterdam, 207-289.

Howarth, R.J. \& Thompson, M. 1976. Duplicate analysis in geochemical practice. II. Examination of the proposed method and examples of its use. Analyst, London, 101, 699-709.

Howarth, R.J. \& Thornton, I. 1983. Regional geochemical mapping and its application to environmental studies. In: Thornton, I. (ed.) Applied Environmental Geochemistry. Academic Press, London, 41-73.

Howarth, R.J. \& Turner, M.S. 1987. Statistical graphics in geochemical journals. Journal of Mathematical Geology, 19, 1-24.

Howarth, R.J. \& Webb, J.S. 1979. Regional geochemical mapping. Philosophical Transactions of the Royal Society, B288, 81-93.

Howarth, R.J., White, C.M. \& Koch, G.S. 1980. On Zipf's Law applied to resource prediction. Transactions of the Institution of Mining and Metallurgy, London, B89, 182-190.

Hunt, A., Johnson, D., Watt, J.M., Crutcher, R.L. \& Thornton, I. 1988. A general purpose scheme for classifying lead-bearing particles by SEM/ EDX. In: Perry, R. \& Kirk, P.W. (eds) Indoor and Ambient Air Ouality. Proceedings of the International Conference on Indoor and Ambient Air Quality, June 13-15 1988, Imperial College, London. Selper, London, 539-546.

Hunt, A., Johnson, D.L., Thornton, I. \& Watt, J.M. 1988. Apportionment of lead-bearing particles in housedust by SEM/AIA/EDX. In: Proceedings of the 2nd Conference on Aerosols, their Generation, Behaviour and Applications. The Aerosol Society, Portishead, Bristol.

Hunt, E.C., Stanton, R.E. \& Wells, R.A. 1960. Field determination of beryllium in soils for geochemical prospecting. Transactions of the Institution of Mining and Metallurgy, 69, 361-369 [Discussion, 69, 642-643].

Jacobson, J.D. 1956. Geochemical prospecting studies in the Kilembe area, Uganda. Dispersion of copper in the soil. Technical Communication, $\mathbf{6}$ Geochemical Prospecting Research Centre, Imperial College of Science and Technology, London.

Jacobson, R.E.E. \& Webb, J.S. 1946. The pegmatites of Central Nigeria. Geological Survey of Nigeria. Bulletin, 17.

JaCobson, R.[E.E.]. \& WebB, J.S. 1947. The occurrence of nigerite, a new tin mineral in quartz-sillimanite-rocks from Nigeria. Mineralogical Magazine, 28 118-128.

James, C.H. 1956. The geochemical dispersion of arsenic and antimony related to gold mineralization in Southern Rhodesia. Technical Communication, 12. Geochemical Prospecting Research Centre, Imperial College of Science and Technology, London.

James, C.H. 1957. Geochemical prospecting studies in the Great Dyke chromite district, Southern Rhodesia. Technical Communication, 13. Geochemical Prospecting Research Centre, Imperial College of Science and Technology, London.

James, C.H. 1961. The geochemistry of mercury (excluding analytical aspects) and its application to geochemical prospecting. Technical Communication, 41. Geochemical Prospecting Research Centre, Imperial College of Science and Technology, London.

James, C.H. 1964a. The application of white spirit as a solvent for dithizone in geochemical analysis for copper in tropical climates. Economic Geology, 59, 1596-1599.

James, C.H. 1964b. The potential role of mercury in modern geochemical prospecting. Mining Magazine, 111, 23-32.

James, C.H. (ed.). 1965. Research in applied geochemistry. Progress Report no. 1. Applied Geochemistry Research Group, Geology Department, Imperial College of Science and Technology, London.

JAmEs, C.H. 1970. A rapid method for calculating the statistical precision of geochemical analysis. Transactions of the Institution of Mining and Metallurgy, B79, 88-89. 
James, C.H. \& Webb, J.S. 1964. Sensitive mercury vapour meter for use in geochemical prospecting. Transactions of the Institution of Mining and Metallurgy, 73, 633-641.

Johnson, C.A. \& Thornton, I. 1987. Hydrological and chemical factors controlling the concentrations of iron, copper, zinc and arsenic in a river system controlled by acid mine drainage. Water Research, 21, 359-365.

Johnson, D.L., Fortmann, R. \& Thornton, I. 1982. Individual particle characterization of heavy-metal rich household dusts. In: HemphiLL, D.D. (ed.) Trace Substances in Environmental Health XVI. University of Missouri, Columbia, MS, 116-123.

Johnson, D.L.J., Watt, J. \& Culbard, E.B. 1985. Automated image analysis and scanning electron microscopy as an aid to tracing the sources of lead in household and other dusts. In: LekKas, T.D. (ed.) Proceedings of the Fifth International Conference on Heavy Metals in the Environment, Athens, September 1985. CEP Consultants, Edinburgh, 2, 404-406.

Jordan, W.J., Alloway, B.J. \& Thornton, I. 1975. The application of regional geochemical reconnaissance data in areas of arable cropping. Journal of the Science of Food and Agriculture, 26, 1413-1424.

Katz, H.R. \& Glasby, G.P. 1979. Mineral resources of the New Zealand Offshore Region. South Pacific Marine Geological Notes, 1, 95-110.

Kinniburgh, D.G. \& Beckett, P.H.T. 1983. Geochemical mapping in Oxfordshire: a comparison of stream sediment and soil sampling. European Journal of Soil Science, 34, 183-203.

Koch, G.S., Carpenter, R.H. \& Howarth, R.J. 1978. Statistical cartography of geochemical data from the Winston-Salem AMS Sheet [abstract]. Society of Mining Engineers - American Institute of Mining Engineers Fall Meeting, September 1978, Orlando, Florida.

Koch, G.S., Carpenter, R.H. \& Howarth, R.J. 1981. Mineral Exploration Using the Department of Energy's Hydrogeochemical and Stream-sediment Reconnaissance data. Short Course, March 23-24, 1981. Short-Course Notes, University of Nevada, Reno.

Кoch, G.S., Howarth, R.J., Carpenter, R.H. \& Schuenemeyer, J.H. 1980 Development of data enhancement and display techniques for stream-sediment data collected in the National Uranium Resource Evaluation Program of the United States Department of Energy. U.S. Department of Energy, Grand Junction, Colorado. Open-file Report, GJBX-28(80).

Koch, G.S., Howarth, R.J. \& Schuenemeyer, J.H. 1980. Uranium resource assessment through statistical analysis of uranium exploration and other data. Society of Mining Engineers - American Institution of Mining Engineers Fall Meeting, Minneapolis. Preprint SME-AIME 80-313.

Koch, G.S., Howarth, R.J. \& Schuenemeyer, J.H. 1981. Uranium resource assessment through statistical analysis of exploration geochemical and other data. Final report. U.S. Department of Energy, Grand Junction, Colorado. Open-file Report, GJBX-140(81).

Koch, G.S., Howarth, R.J., Schuenemeyer, J.H. \& Lowry, R.K. 1981. Uranium resource assessment through statistical analysis of exploration geochemical and other data. Economic Geology, 76, 1056-1066.

Koksoy, M. \& Bradshaw, P.M.D. 1969. Secondary dispersion of mercury from cinnabar and stibnite deposits, West Turkey. Quarterly Journal of the Colorado School of Mines, 64, 333-356.

Koksoy, M., Bradshaw, P.M.D. \& Tooms, J.S. 1967. Notes on the determination of mercury in geological samples. Transactions of the Institution of Mining and Metallurgy, B76, 121-124.

Leech, A., Howarth, R.J., Thornton, I. \& Lewis, G. 1982. The incidence of bovine copper deficiency in England and the Welsh Borders - the current situations. Veterinary Record, 111, 203-204.

Leech, A.F. \& Thornton, I. 1987. Trace elements in soils and pasture herbage on farms with bovine hypocupraemia. Journal of Agricultural Science, Cambridge, 108, 591-597.

Leech, A.F., Thornton, I., Howarth, R.J. \& Lewis, I. 1983. The incidence of bovine hyprocupraemia in England and Wales and its relationship with geochemistry. In: SutTle, N.F. (ed.) Trace elements in animal production and veterinary practice. British Society for Animal Production, 130-131.

Lovell, J.S. \& Hale, M. 1983. Application of soil-air carbon dioxide and oxygen measurements to mineral exploration. Transactions Institution of Mining and Metallurgy, London, B92, 28-32.

Lovell, J.S., Hale, M. \& Webb, J.S. 1979. Soil air disequilibria as a guide to concealed mineralisation at Keele, Eire. In: Davis, G.R. (ed.) Prospecting in Areas of Glaciated Terrain 1979. Institution of Mining and Metallurgy. 45-50.

Lovell, J.S., Hale, M. \& Webb, J.S. 1980. Vapour geochemistry in mineral exploration. Mining Magazine, 143, 229-239.

Lovell, J.S., Hale, M. \& Webb, J.S. 1983. Soil air carbon dioxide and oxygen measurements as a guide to concealed mineralization in semi-arid and arid regions. Journal of Geochemical Exploration, 19, 305-317.
Lowenstein, P.L. \& Howarth, R.J. 1973a. Primary regional geochemical reconnaissance of southwest England [Abstract]. Proceedings of the Ussher Society, 2, 478-479.

Lowenstein, P.L. \& Howarth, R.J., 1973b. Automated colour mapping of three-component systems and its application to regional geochemical reconnaissance. In: Jones, M.J. (ed.) Geochemical Exploration 1972. Institution of Mining and Metallurgy, London. 297-304.

Mackay, D.W., Halcrow, W. \& Thornton, I. 1972. Sludge dumping in the Firth of Clyde. Marine Pollution Bulletin, 3, 7-10.

Malahoff, A., Embley, R.W., Cronan, D.S. \& Skirrow, R. 1983. The geological setting and chemistry of hydrothermal sulfides and associated deposits from the Galapagos Rift at $86^{\circ} \mathrm{W}$. Marine Mining, 4, 123-137.

ManCey, S.J. 1982. Cluster analysis in geology. In: Horder, M.F. \& Hownath, R.J. (eds) Computer Applications in Geology I \& II. Geological Society of London Miscellaneous Paper, 14, 89-102.

MANCEY, S.J. \& HowARTH, R.J. 1978. Factor score maps of regional geochemical data from England and Wales. Applied Geochemistry Research Group, Imperial College of Science, Technology and Medicine, London. 2 sheets.

Mancey, S.J. \& Howarth, R.J. 1980a. Dimensionality reduction applied to the regional geochemistry of England and Wales [Abstract]. Journal of the Geological Society, London, 137, 108-109.

Mancey, S.J. \& Howarth, R.J. 1980b. Power transform removal of skewness from large data sets. Transactions of the Institute of Mining and Metallurgy, B89, 92-97.

Marples, A.E. \& Thornton, I. 1980. The distribution of cadmium derived from geochemical and industrial sources in agricultural soils and pasture herbage in parts of Britain. In: Proceedings of the 2nd International Cadmium Conference, Cannes, February 6-8, 1979. Metal Bulletin, London, 74-79.

Matthews, H. \& Thornton, I. 1980. Agricultural implications of zinc and cadmium contaminated land at Shipham, Somerset. In: Hemphill, D.D. (ed.) Trace Substances in Environmental Health XIV. University of Missouri, Columbia, MS, 478-488.

Matthews, H. \& Thornton, I. 1982a. Cadmium in the farming environment at Shipham. In: Wilson, D. \& Volpe, R.A. (eds) Cadmium 81: Edited Proceedings, Third International Cadmium Conference, Miami, USA, 3-5 February 1981. Cadmium Association, London, and Cadmium Council, New York.

Matthews, H. \& Thornton, I. 1982b. Seasonal and species variation in the content of cadmium and associated metals in pasture plants at Shipham. Plant and Soil, 66, 181-193.

Mattigod, S.V., Page, A.L. \& Thornton, I. 1986. Identification of some trace metal minerals in a mine-waste contaminated soil. Soil Science Society of America Journal, 50, 254-258.

Mazzucchelli, R.H. \& James, C.H. 1966. Arsenic as a guide to gold mineralization in laterite-covered areas of Western Australia. Transactions of the Institution of Mining and Metallurgy, B75, 286-294.

McDonald, A.J. \& Stanton, R.E. 1962. The spectrophotometric determination of tin in the soils with gallein. Analyst, London, 87, 600-602.

Mehrtens, M.B., Tooms, J.S. \& Troup, A.G. 1973. Some aspects of geochemical dispersion from base-metal mineralization within glaciated terrain in Norway, North Wales and British Columbia, Canada. In: Jones, M.J. (ed.) Geochemical Exploration 1972. Institution of Mining and Metallurgy, London, 105-115.

Meyer, W.T. \& Evans, D.S. 1973. Dispersion of mercury and associated elements in a glacial drift environment at Keel, Eire. In: Jones, M.J. (ed.) Prospecting in areas of glacial terrain. Institution of Mining and Metallurgy, London, 127-138.

Meyer, W.T. \& Lam Shang Leen, K.C.Y. 1973. Microwave-induced argon plasma emission system for geochemical trace analysis. In: Jones, M.J. (ed.) Geochemical Exploration 1972. Institution of Mining and Metallurgy, London, 325-335.

Meyer, W.T., Lovell, J.S. \& Hale, M. 1986. Detection of concealed mineral and energy resources by vapour geochemistry. In: Thornton, I. \& Hownarth, R.J. (eds) Applied Geochemistry in the 1980s. Graham \& Trotman, London, 86-102.

Meyer, W.T. \& Peters, R.G. 1973. Evaluation of sulphur as a guide to buried deposits in the Notre Dame Bay area, Newfoundland. In: Jones, M.J. (ed.) Geochemical Exploration 1972. Institution of Mining and Metallurgy, London, $55-66$.

Mill, A.J.B. 1980a. Colloidal and macromolecular forms of iron in natural waters. 1: A review. Environmental Technology Letters, 1, 97-108.

Mill, A.J.B. 1980b. Colloidal and macromolecular forms of iron in natural waters. 2: Their occurrence in rivers of southwest England. Environmental Technology Letters, 1, 109-123.

Millman, A.P. 1950. Geochemical prospecting by the field analysis of surface waters. Mine and Quarry Engineering, 16, 145-148. 
Millman, A.P. 1957. Biogeochemical investigation in areas of copper-tin mineralization in S.W. England. Geochimica et Cosmocbimica Acta, 12, 85-93.

Mindszenty, A., GalÁcz, A., Dódony, I. \& Cronan, D.S. 1986. Palaeoenvironmental significance of ferromanganese oxide concretions from the Hungarian Jurassic. Chemie der Erde - Geochemistry, 45, 177-190.

Mitra, S. \& Webb, J.S. 1967. Mercury in Southwest England [Discussion]. Transactions of the Institution of Mining and Metallurgy, B76, 180.

Moon, C.H. \& Thornton, I. 1988. Differential thermal extraction of lead species in mine-waste contaminated soils and dusts. Environmental Technology Letters, 9, 1367-1372.

Moorby, S.A. \& Cronan, D.S. 1981. The distribution of elements between co-existing phases in some marine ferromanganese-oxide deposits. Geochimica et Cosmochemica Acta, 45, 1855-1877.

Moorby, S.A. \& Cronan, D.S. 1983. The geochemistry of hydrothermal and pelagic sediments from the Galapagos Hydrothermal Mounds Field, D.S.D.P. Leg 70. Mineralogical Magazine, 47, 291-300.

Moorby, S.A., Cronan, D.S. \& Glasby, G.P. 1984. Geochemistry of hydrothermal manganese-oxide deposits from the S.W. Pacific island arc. Geochimica et Cosmochemica Acta, 48, 433-441.

Moorby, S.A., Cronan, D.S., Perissoratis, C. \& Sakellariadou, F. 1988. A statistical analysis of geochemical data in regard to placer mineral exploration in the Aegean Sea. Marine Mining, 8, 439-456.

Moorby, S.A., Howarth, R.J. \& Smith, P.A. 1987. An investigation of the applicability of trend surface analysis to marine exploration geochemistry. In: Teleki, P.G., Dobson, M.R., Moore, J.R. \& von Stackelberg, U. (eds) Marine Minerals: Advances in Research and Resource Assessment (NATO ASI series. Series C: Mathematical and Physical Sciences, 194. D. Reidel, Dordrecht, 559-576.

Moorby, S.A., Varnavas, S.P. \& Cronan, D.S. 1983. Geochemistry of sediments from the East Pacific Rise at $23^{\circ} \mathrm{N}$. In: Lewis, B.T.R., Robinson, P.T., Benson, R.N., Blackinton, G., Cambon, P., Day, R., Duennebier, F., Flower, M.J.F., Gutiérrez-Estrada, M., Hattiner, J.G., Kudo, A.M., Morrison, M.A., Rangin, C., Salisbury, M.H., Schmincke, H.-U., Steven, R. \& Zolotarev, B.P. (eds) Initial Reports of the Deep Sea Drilling Project, 65. U.S. Government Printing Office, Washington, 425-430.

Moorcroft, S., Watt, J., Thornton, I., Wells, J., Strehlow, C.D. \& Barltrop, D. 1982. Composition of dusts and soils in an apparently uncontaminated rural village in southwest England - Implications to human health. In: Hemphill, D.D. (ed.) Trace Substances in Environmental Health XVT. University of Missouri, Columbia, MS, 155-163.

Murty, P.S.N., Cronan, D.S., Rao, C.M., Paropkaria, L., Topgi, R.S., Guptham, V.S. \& Colley, N. 1983. Geochemistry of sediment cores of the western equatorial Indian Ocean. Mahasagar, Goa, 16, 9-29.

Nichol, I. \& Henderson-Hamilton, J.C. 1965. A rapid quantitative spectrographic method for the analysis of rocks, soils and stream sediments. Transactions of the Institution of Mining and Metallurgy, 74, 955-961.

Nichol, I. \& WebB, J.S. 1967. The application of computerized mathematical and statistical procedures to the interpretation of geochemical data. Proceedings of the Geological Society of London, 1642, 186-198 [Discussion, 198-199].

Nichol, I., Garrett, R.G. \& Webb, J.S. 1966a. Studies in regional geochemistry. Transactions of the Institution of Mining and Metallurgy, B75, 106-107.

Nichol, I., Garrett, R.G. \& Webb, J.S. 1966b. Automatic data plotting and mathematical and statistical interpretation of geochemical data. Transactions, Geochemical Prospecting Symposium. Geological Survey of Canada Paper, 66-54, 195-209.

Nichol, I., Horsnail, R.F. \& Webb, J.S. 1966c. Geochemical patterns in stream sediment related to precipitation of manganese oxides. Transactions of the Institution of Mining and Metallurgy, B76, 113-115.

Nichol, I., James, L.D. \& Viewing, K.A. 1966d. Regional geochemical reconnaissance in Sierra Leone. Transactions of the Institution of Mining and Metallurgy, B75, 146-161 [Discussion, B76, 69-70, 113-115; B78, 52-54].

Nichol, I., Garrett, R.G. \& Webb, J.S. 1969. The role of some statistical and mathematical methods in the interpretation of regional geochemical data. Economic Geology, 64, 204-220 [Discussion, 64, 830; Authors' reply to discussion, 65, 593-594].

Nichol, I., Thornton, I., Webb, J.S., Fletcher, W.K., Horsnail, R.J., KhaleElee, J. \& TAYlor, D. 1970a. Regional geochemical reconaissance of the Derbyshire area. Institute of Geological Sciences, London, Report 70/2.

Nichol, I., Thornton, I., Webb, J.S., Fletcher, W.K., Horsnail, R.J., Khaleelee, J. \& TAYlor, D. 1970b. Regional geochemical reconaissance of the Denbighshire area. Institute of Geological Sciences, London, Report 70/8.

Nichol, I., Thornton, I., Webb, J.S., Fletcher, W.K., Horsnail, R.J. \& Khaleelee, J. 1971. Regional geochemical reconaissance of the Devon and North Cornwall area. Institute of Geological Sciences, London, Report 71/2.
Nicholls, O.W., Provan, D.M., Cole, M.M. \& Tooms, J.S. 1965. Geobotany and geochemistry in mineral exploration in the Dugald River Area, Cloncurry District, Australia. Transactions of the Institution of Mining and Metallurgy, 74, 695-799 [Discussion, B75, 168-171, B78, 98-100; Authors' reply to discussion, $\mathbf{B} 75,307-310]$.

Oakes, B.W. \& Hale, M. 1987. Dispersion patterns of carbonyl sulphide above mineral deposits. Journal of Geochemical Exploration, 28, 235-250.

Olson, B.H. \& Thornton, I. 1982. The resistance patterns to metals of bacterial populations in contaminated land. European Journal of Soil Science, 33, 271-277.

Pahlavanpour, B. \& Thompson, M. 1981. The determination arsenic species by selective reduction. Proceedings of the International Conference on Heavy Metals in the Environment, September 1981, Amsterdam. CEP Consultants, Edinburgh, 661-664.

Pahlavanpour, B., Thompson, M. \& Walton, S.J. 1979. The determination of tin in geochemical samples by inductively coupled plasma atomic emission spectrometry. Journal of Geochemical Exploration, 12, 45-55.

Pahlavanpour, B., Pullen, J.H. \& Thompson, M., 1980a. The determination of trace concentrations of selenium in soils and sediments by the introduction of hydrogen selenide into an inductively coupled plasma source for emission spectrometry. Analyst, London, 105, 274-278.

Pahlavanpour, B., Thompson, M. \& Thorne, L. 1980b. Simultaneous determination of arsenic, antimony and bismuth in soils and sediments by volatile hydride generation and inductively coupled plasma emission spectrometry. Analyst, London, 105, 756-761.

Pahlavanpour, B., Thompson, M. \& Thorne, L. 1981 $a$. The simultaneous determination of trace amounts of arsenic, antimony and bismuth in herbage by hydride generation and inductively coupled plasma atomic emission spectrometry. Analyst, London, 106, 467-471.

Pahlavanpour, B., Thompson, M. \& Thorne, L. 1981b. The simultaneous determination of arsenic, antimony, bismuth, selenium and tellurium in waters by an inductively coupled plasma - volatile hydride method. Water Research, 15, 407-411.

Perissoratis, C., Moorby, S.A., Papavasiliou, C., Cronan, D.S., Angepoulos, I., Sakellariadou, F. \& Mitropoulos, D. 1987. The geology and geochemistry of the surficial sediments off Thraki, northern Greece. Marine Geology, 74, 209-224.

Prior, R.N., Taylor, J., Verney, R., Dunstan, L.M., Drew, R.L., Thornton, I., Allen, P. \& Dunham, K. 1974. General discussion. Proceedings of the Royal Society, London, A339, 411-416.

Ramsey, M.H. \& Thompson, M. 1981. On-line diluter for atomic absorption spectrophotometry. Analyst, London, 107, 232-234.

Ramsey, M.H. \& Thompson, M. 1982. AAS and ICP: Complementary methods for the minerals industry. Sampling and Analysis for the Minerals Industry: papers presented at a symposium organized by the Institution of Mining and Metallurgy and held in London on 2 November 1982. Institution of Mining and Metallurgy, London, 63-72.

Ramsey, M.H. \& Thompson, M. 1985. Correlated variance in simultaneous ICPAES; its causes and correction by a parameter-related internal standard method. Analyst, London, 110, 519-530.

Ramsey, M.H. \& Thompson, M. 1986. A predictive model of plasma matrix effects in ICPAES. Journal of Analytical Atomic Spectrometry, 1, 185-193.

Ramsey, M.H. \& Thompson, M. 1987. High-accuracy analysis by inductively coupled plasma atomic emission spectrometry using the parameter-related internal standard method. Journal of Analytical Atomic Spectrometry, 2, 497 502.

Ranasinghe, W.C., Thomas, B.W. \& Cronan, D.S. 1988. Application of nuclear techniques to marine mineral exploration. Marine Minerals, 7, 291-316.

Rankin, A.H., Alderton, D.H.M., Thompson, M. \& Goulter, J.E. 1982. Determination of uranium:carbon ratios in fluid inclusion decrepitates. Mineralogical Magazine, 46, 179-186.

Rhind, D.W., Shaw, M.A. \& Howarth, R.J. 1973. Experimental cartographic map - a case study in cartographic techniques for scientific research. Cartographic Journal, 10, 112-118.

Rose, A.W., Hawnes, H.E. \& Webb, J.S. 1979. Geochemistry in Mineral Exploration. 2nd ed. Academic Press, London, New York, Toronto, Sydney and San Francisco.

Rother, J.A., Millbank, J.W. \& Thornton, I. 1982. Seasonal fluctuations in nitrogen fixation (acetylene reduction) by free-living bacteria in soils contaminated with cadmium, lead and zinc. European Journal of Soil Science, 33, 101-113.

Rother, J.A., Millbank, J.W. \& Thornton, I. 1983. Nitrogen fixation by white clover (Trifolium repens) in grasslands on soils contaminated with cadmium, lead and zinc. European Journal of Soil Science, 34, 127-136. 
Ruan, T., Hale, M. \& Howarth, R.J. 1985. Numerical modelling experiments in vapour geochemistry. II: Implications for mineral exploration. Journal of Geochemical Exploration, 23, 265-280.

Ruan, T.J., Howarth, R.J. \& Hale, M. 1985. Numerical modeling experiments in vapour geochemistry. I: method and Fortran programme. Computers \& Geosciences, 11, 55-67.

Russell, K., Brebner, J., Thornton, I. \& Suttle, N.F. 1985. The influence of soil ingestion on the intake of potentially toxic metals and absorption of essential trace elements by grazing livestock. In: Mills, C.F., Bremner, I. \& Chesters, J.K. (eds) TEMA 5, Proceedings of the fifth International Symposium on Trace Elements in Man and Animals. Commonwealth Agricultural Bureau, Farnham Royal, Slough, 847-849.

Shearme, S., Cronan, D.S. \& Rona, P.A. 1983. Geochemistry of sediments from the TAG Hydrothermal Field, MAR at 26 degrees North. Marine Geology, 51, 269-291.

Skirrow, R. \& Coleman, M.L. 1982a. Origin of sulphur and geothermometry of hydrothermal sulphides from the Galapagos Rift, $86^{\circ} \mathrm{W}$. Nature, London, 299, 142-144.

Skirrow, R. \& Coleman, M.L. 1982b. Stable isotope evidence for the evolution of Galapagos Rift inactive hydrothermal sulphide mounds, at $86^{\circ} \mathrm{W}$. Institute of Geological Sciences Isotope Geology Unit Stable Isotope Report, 76.

Smith, P.A. \& Cronan, D.S. 1975a. Dispersion of metals associated with a submarine exhalative deposit. Proceedings, Oceanology International '75, March 16th-21st 1975, Brighton, England. BPS Exhibitions, London, 1, 111-114.

Smith, P.A. \& Cronan, D.S. 1975a. Chemical composition of Aegean Sea sediments. Marine Geology, 18, M7-M11.

Smith, P.A. \& Cronan, D.S. 1978. Geochemical dispersion of metals in and around the caldera of Thera. In: Doumas, C. \& Puchelt, H.C. (eds) Thera and the Aegean World: Papers presented at the Second International Scientific Congress, Santorini, Greece, August 1978. Thera and the Agean World, London, 344-361

Smith, P.A. \& Cronan, D.S. 1983. The geochemistry of metalliferous sediments and waters associated with shallow submarine hydrothermal activity (Santorini, Aegean Sea). Chemical Geology, 39, 241-262.

SozANSKI, A. \& CRONAN, D.S. 1976. Environmental differentiation of morphology of ferromanganese oxide concretions in Shebandowan lakes, Ontario. Limnology and Oceanography, 21, 894-898.

Sozanski, A. \& Cronan, D.S. 1979. Ferromanganese oxide concretions in Shebandowan lakes, Ontario. Canadian Journal of Earth Sciences, 16, 126-140.

Stanton, R.E. 1959. Dithizone field colorimetry. [Discussion]. Economic Geology, 54, 1577-1578.

Stanton, R.E. 1964a. Dithizone field tests. [Discussion]. Economic Geology, 59, 1178-1179.

Stanton, R.E. 1964b. The field determination of arsenic in soils and sediments. Economic Geology, 59, 1599-1602.

Stanton, R.E. 1966. Rapid methods of Trace Analysis for Geochemical Application. Edward Arnold, London.

Stanton, R.E. \& Coope, J.A. 1958. Modified field test for the determination of small amounts of nickel in soils and rocks. Transactions of the Institution of Mining and Metallurgy, 68, 9-14.

Stanton, R.E. \& Hardwick, A.J. 1967. The colorimetric determination of molybdenum in soils and sediments by zinc dithiol. Analyst, London, $\mathbf{9 2}$ 387-390.

Stanton, R.E. \& Hardwick, A.J. 1968. The determination of molybdenum in milk with zinc dithiol. Analyst, London, 93, 193.

Stanton, R.E. \& McDonald, A.J. 1960. Application of automated analysis to the determination of zinc, lead, molybdenum and nickel in extracts of soils. Chemistry and Industry, 39, 1406-1407.

Stanton, R.E. \& McDonald, A.J. 1961a. Field determination of tin in geochemical soil and stream sediment surveys. Transactions of the Institution of Mining and Metallurgy, 71, 27-29.

Stanton, R.E. \& McDonald, A.J. 1961b. Field determination of cobalt in soil and sediment samples. Transactions of the Institution of Mining and Metallurgy, 71, 511-516 [Discussion, 72, 55-56].

Stanton, R.E. \& McDonald, A.J. 1961c. Field determination of antimony in soil and sediment samples. Transactions of the Institution of Mining and Metallurgy, 71, 517-522.

Stanton, R.E. \& McDonald, A.J. 1961d. Application of automated analysis to the determination of zinc, lead, molybdenum and nickel in extracts of soils. Chemistry and Industry, 39, 1406-1407.

Stanton, R.E. \& McDonald, A.J. 1961e. The spectrophotometric determination of antimony with Brilliant green. Analyst, London, 87, 299-301.

Stanton, R.E. \& McDonald, A.J. 1963. Application of the AutoAnalyser to the determination of zinc in soils and sediments. Analyst, London, 88, 608-613.
Stanton, R.E. \& McDonald, A.J. 1964. The determination of gold in soil with Brilliant green. Analyst, London, 89, 767-770.

Stanton, R.E. \& McDonald, A.J. 1965. The determination of selenium in soils and sediments with 3,3'-diaminobenzidine. Analyst, London, 90, 497-499.

Stanton, R.E. \& McDonald, A.J. 1966. The colorimetric determination of boron in soils, sediments and rocks with Methylene blue. Analyst, London, 91, 775-778.

Stanton, R.E., McDonald, A.J. \& Carmichael, I. 1962. The determination of some trace elements in silicate rocks. Analyst, London, 87, 134-139.

Summerhayes, C.P. 1969. Submarine geology and geomorphology off Northern New Zealand. New Zealand Journal of Geology and Geophysics, 12, 507-525.

Summerhayes, C.P. 1972. Geochemistry of continental margin sediments from northwest Africa. Chemical Geology, 10, 137-156.

Summerhayes, C.P., Hazelhoff-Roelfzema, B., Tooms, J.S. \& Smith, D.B. 1970. Phosphorite prospecting using a submersible scintillation counter. Economic Geology, 65, 718-723.

Summerhayes, C.P., Nutter, A.H. \& Tooms, J.S. 1971. Geological structure and development of the continental margin of northwest Africa. Marine Geology, 11, 1-25.

Summerhayes, C.P., Nutter, A.H. \& Tooms, J.S. 1972. The distribution and origin of phosphate in sediments off northwest Africa. Sedimentary Geology, 8, 3-28.

Suttle, N.F., Abrahams, P.W. \& Thornton, I. 1982. The importance of soil type and dietary sulphur in the impairment of copper absorption in sheep which ingest soil. Proceedings of the Nutrition Society, 41, A83.

Suttle, N.F., Abrahams, P.W. \& Thornton, I. 1984. The role of soil $\times$ dietary sulphur interaction in the impairment of copper absorption by ingested soil in sheep. Journal of Agricultural Science, Cambridge, 103, 81-86.

Suttle, N.F., Alloway, B.J. \& Thornton, I. 1975. An effect of soil ingestion on the utilisation of dietary copper by sheep. Journal of Agricultural Science, 84, 249-254.

Taylor, D., Nichol, I. \& Webb, J.S. 1967. Enrichment of base metals in the Triassic sandstones of south Derbyshire. Transactions of the Institution of Mining and Metallurgy, B76, 214-215.

Thomas, J.F.A., Culbard, E.B., Harvey, P.G., Sherlock, J.G., Delves, T., Davies, D.J.A., Quinn, M.J., Morgan, J., Smart, G., Spurgeon, A., Thornton, I. \& WATT, J. 1985. Lead intakes of young children from dusts and other sources. In: Lekkas, T.D. (ed.) Proceedings of the Fifth International Conference on Heavy Metals in the Environment, Athens, September 1985. CEP Consultants, Edinburgh, 1, 317-320.

Thompson, A.J. \& Thoresby, P. 1977. Determination of arsenic in soil and plant materials by atomic absorption spectrophotometry with electrothermal atomisation. Analyst, London, 102, 9-16.

Thompson, M. 1978. DUPAN3, A subroutine for the interpretation of duplicated data in geochemical analysis. Computers \& Geosciences, 11 333-340.

Thompson, M. 1983a. Control procedures in geochemical analysis. In: Howarth, R.J. (ed.) Statistics and Data Analysis in Geochemical Prospecting. Elsevier, Amsterdam, 39-58.

Thompson, M. 1983b. Regression methods in the comparison of accuracy. Analyst, London, 107, 1169-1180.

Thompson, M. 1983c. Analytical methods in applied environmental geochemistry. In: Thornton, I. (ed.) Applied Environmental Geochemistry. Academic Press, London, 75-101.

Thompson, M. 1985. The capabilities of ICPAES - some conjectures and refutations. Analyst, London, 110, 443-44.

Thompson, M., Goulter, J.E. \& Sieper, F. 1981a. Laser ablation for the introduction of solid samples into an inductively coupled plasma for atomic emission spectrometry. Analyst, London, 106, 32-39.

Thompson, M., Goulter, J.E. \& Sieper, F. 1981b. Verdampfung gester proben im lasterstrahl des LMA 10 und ihre zuführune in induktivgekoppeltes plasma (ICP) für die atom-emissionsspektrometrie. Jena Review, 5, 202-205.

Thompson, M. \& Hale, M. 1984. Rapid identification of heavy minerals by laser ablation inductively coupled plasma emission spectrometry. In: JONES, M.J. (ed.) Prospecting in Areas of Glaciated Terrain 1984. Special Publication, Institution of Mining and Metallurgy, London, 225-232.

Thompson, M. \& Howarth, R.J. 1973. The rapid estimation and control of precision by duplicate determinations. Analyst, London, 98, 153-160.

Thompson, M. \& Howarth, R.J. 1976. Duplicate analysis in geochemical practice. I. Theoretical approach and estimation of analytical reproducibility. Analyst, London, 101, 690-698.

Thompson, M. \& Jones, D.J.W. 1976. Auto standardization in spectrophotometry. Analyst, London, 101, 825-827. 
Thompson, M. \& Howarth, R.J. 1978. A new approach to the estimation of analytical precision. Journal of Geochemical Exploration, 9, 23-30.

Thompson, M. \& Howarth, R.J. 1980. The frequency distribution of analytical error. Analyst, London, 105, 1188-1195.

Thompson, M. \& Pahlavanpour, B. 1979. Reduction of tin and germanium to hydrides for determination by inductively coupled plasma atomic emission spectrometry. Analytica Chimica Acta, 109, 251-258.

Thompson, M. \& Ramsey, M.H. 1985. Matrix effects due to calcium in icpaes: their nature, source and remedy. Analyst, London, 110, 1413-1422.

Thompson, M. \& Walsh, J.N. 1983. A Handbook of Inductively Coupled Plasma Spectrometry. Blackie, Glasgow and London.

Thompson, M. \& WebB, J.S. 1978. Analytical requirements in exploration geochemistry. Pure and Applied Chemistry, 49, 1507-1518.

Thompson, M. \& Wood, S.J. 1982. Atomic absorption methods in applied geochemistry. In: Cantle, J.E. (ed.) Atomic Absorption Spectrometry. Elsevier, Amsterdam, Oxford and New York. 261-284.

Thompson, M., Pahlavanpour, B., Walton, S.J. \& Kirkbright, G.F. $1978 a$. Simultaneous determination of trace concentrations of arsenic, antimony, bismuth, selenium and tellurium in aqueous solution by introduction of the gaseous hydrides into an inductively-coupled plasma source for emission spectrometry. Part I: Preliminary studies. Analyst, London, 103, 568-579.

Thompson, M, Pahlavanpour, B., Walton, S.J. \& Kirbright, G.F. $1978 b$. Simultaneous determination of trace concentrations of arsenic, antimony, bismuth, selenium and tellurium in aqueous solution by introduction of the gaseous hydrides into an inductively-coupled plasma source for emission spectrometry. Part II. Interference studies. Analyst, London, 103, 705-713.

Thompson, M., Thorne, L.T. \& Pahlavanpour, B. 1979a. Inductively coupled plasma spectrometry (ICP) and hydride generation for the determination of toxic elements in earth materials and surface waters. Proceedings of the second international conference on the management and control of heavy metals in the environment. London. CEP Consultants, Edinburgh, 398-401.

Thompson, M., Walton, S.J. \& Wood, S.J. 1979b. Statistical appraisal of interference effects in the determination of trace elements by atomic absorption spectrometry in applied geochemistry. Analyst, London, 104, 299-312.

Thompson, M., Rankin, A.H., Walton, S.J., Halls, C. \& Foo, B.N. 1980. The analysis of fluid inclusion decrepitate by inductively coupled plasma atomic emission spectrometry: an exploratory study. Chemical Geology, 30, 121-133.

Thompson, M., Pahlavanpour, B. \& Thorne, L.T. 1981. The simultaneous determination of arsenic, antimony, bismuth, selenium and tellurium in waters by an inductively coupled plasma - volatile hydride method. Journal of Water Research, 15, 403-411.

Thompson, M., Ramsey, M.H. \& Coles, B.J. 1982a. Interactive matrix matching - A new method of correcting interference effects in inductively coupled plasma spectrometry. Analyst, London, 107, 1286-1288.

Thompson, M., Ramsey, M.H. \& Pahlavanpour, B. 1982b. Water analysis by inductively coupled plasma atomic-emission spectrometry after a rapid pre-concentration. Analyst, London, 107, 1330-1334.

Thomson, I., Thornton, I. \& WebB, J.S. 1972. Molybdenum in black shales and the incidence of bovine hypocuprosis. Journal of the Science of Food and Agriculture, 23, 871-891.

Thorne, L.T., Thornton, I., Reynolds, B., McCalley, D. \& Metcalf, A. 1979. A geochemical investigation of the disposal of metals in surface drainage systems derived from pollution and geological sources. Proceedings of the second international conference on the management and control of heavy metals in the environment. London. CEP Consultants, Edinburgh, 325-328.

Thorne, L.T., Metcalf, A. \& Thornton, I. 1980. A geochemical investigation of cadmium, lead and zinc in waters and sediments of the River Gannel, Cornwall. In: Hemphill, D.D. (ed.) Trace Substances in Environmental Health XIV. University of Missouri, Columbia, MS, 500-506.

Thornton, I. 1972. Sampling techniques in multi-purpose geochemical reconnaissance surveys. Mining Magazine, London, 82, (March 1972), 225.

Thornton, I. 1973a. Geochemical parameters in estuaries in relation to oyster culture. Proceedings of the Challenger Society, 4.

Thornton, I. 1973b. Geochemical reconnaissance and the environment. Billiton-venture, Christmas 1972, 22-26.

Thornton, I. 1974a. Applied geochemistry on relation to mining and the environment. In: Jones, M.J. (ed.) Minerals and the Environment. Proceedings of an international symposium. Institution of Mining and Metallurgy, London. 87-102.

Thornton, I. 1974b. Biogeochemical and soil ingestion studies in relation to the trace element nutrition of livestock. In: Hoekstra, W.G., Suttie, J.W. Ganther, H.E. \& Mertz, W. (eds) Trace element metabolism in animals 2: Proceedings of the second International Symposium on Trace Element Metabolism in
Animals, beld in Madison, Wisconsin, on 18-22 June, 1973. University Park Press, Baltimore. 451-454.

Thornton, I. 1975a. Geochemical parameters in the assessment of estuarine pollution. In: Chadwick, M.J. \& Goodman, G.T. (eds) The Ecology of Resource Degradation and Renewal: The 15th Symposium of the British Ecological Society Symposium, 10-12 July 1973. British Ecological Society Symposium Volume 15. Blackwell Scientific Publications, Oxford, 157-169.

Thornton, I. 1975b. Applied geochemistry in relation to mining and the environment. In: Jones, M.J. (ed.) Minerals and the environment. Institution of Mining and Metallurgy, London, 87-102.

Thornton, I. $1977 a$. Some aspects of environmental geochemistry in Britain. In: Hutchinson, T.C. (ed.) Proceedings of the 1st International Conference on Heavy Metals in the Environment, Toronto, Ontario, Canada, October 27-31, 1975. Toronto Institute for Environmental Studies, Toronto, 27-31.

Thornton, I. 1977b. Biogeochemical studies on molybdenum in the United Kingdom. In: Chappell, W.R. \& Petersen, K.K. (eds) Molybdenum in the environment. Elsevier, New York, 2, 341-369.

Thornton, I. 1978a. Environmental aspects of cadmium distribution in England and Wales. In: Cole, J. \& Hiscock, S. (eds) Cadmium 77: Proceedings of the First International Cadmium Conference. Metal Bulletin, Worcester Park, England, 109-110.

Thornton, I. 1978b. Contamination of soils and surface waters with trace metals from mining wastes. Transactions of the Institution of Mining and Metallurgy, London, A87, 121-124.

Thornton, I. 1979a. Copper in soils and sediments. In: Nriagu, J.O. (ed.) Copper in the Environment. John Wiley, New York, 172-216.

Thornton, I. 1979b. Cadmium: Shipham in perspective. Chemistry in Britain, $15,223-224$

Thornton, I. 1979c. Geochemical aspects of trace metal interactions. In: Di Ferrante, E. (ed.) Trace metals: Exposure and health effects. Proceedings of the research seminar held at the University of Surrey, Guilford, United Kingdom, 10-13 July, 1978. Published for the Commission of the European Communities. Pergamon, Oxford and New York, 148-157.

Thornton, I. 1980a. Background levels of heavy metals in soils and plants. In: Proceedings of the Conference on Reclamation of Contaminated Land. 22-25 October 1979, Eastborne, United Kingdom. Society of the Chemical Industry, London. C5, 1-12.

Thornton, I. 1980b. Geochemical aspects of heavy metal pollution and agriculture in England and Wales. Inorganic Pollution and Agriculture, Proceedings of a conference beld in London in April 1977. Ministry of Agriculture Fisheries and Food. Reference Book 326. Her Majesty's Stationery Office, London, 105-125.

Thornton, I. 1980c. Heavy metal dispersion in soils and surface waters in old mining areas. Proceedings of the Conference on the Effect and Control of Dispersed Metals in the Environment. Minerals Industries Research Organisation, London.

Thornton, I. 1981. Geochemical aspects of the distribution and forms of heavy metals in soils. In: LEpp, N.W. (ed.) Effect of heavy metal pollution on plants. Volume 2. Metals in the environment. Applied Science Publishers, London, 1-33.

Thornton, I. 1982. Implications of geochemical background data in relation to hazardous waste management. In: Hemphill, D.D. (ed.) Trace Substances in Environmental Health XVT. University of Missouri, Columbia, MS, 57-67.

Thornton, I. (ed.) 1983a. Applied Environmental Geochemistry. Academic Press, London \& New York.

Thornton, I. 1983b. Geochemistry applied to agriculture. In: Thornton, I. (ed.) Applied Environmental Geochemistry. Academic Press, London, 231-266.

Thornton, I. 1986a. Lead in United Kingdom soils and dusts in relation to environmental standards and guidelines. In: Hemphill, D.D. (ed.) Trace Substances in Environmental Health XX. University of Missouri, Columbia, MS, 298-307.

Thornton, I. 1986 b. Biochemical studies on molybdenum in the United Kingdom [in relation to livestock nutrition and human health]. In Chappell, W.R. \& Petersen, K.K. (eds) Molybdenum in the environment: Proceedings of the International Symposium on Molybdenum in the Environment, Denver, Colorado, USA, 1985. Marcel Dekker, New York, 2, 341-369.

Thornton, I. 1987. Mapping of trace elements in relation to human disease. Clinical Nutrition, 6, 97-104.

Thornton, I. (ed.) 1988a. Environmental Geochemistry and Health. Proceedings of the Second International Symposium on Geochemistry and Health, held at the Royal Society, London, 22-24 April 1987. Science Reviews Limited, CRC Press, London.

Thornton, I. 1988b. The Shipham Report. An investigation into cadmium contamination and its implications for human health. Metal content of soils and dusts. Science of the Total Environment, 75, 21-39. 
Thornton, I. \& Abrahams, P.W. 1981a. The role of soil ingestion in the intake of metals by livestock. In: Hemphill, D.D. (ed.) Trace Substances in Environmental Health XV. University of Missouri, Columbia, MS, 366-371.

Thornton, I. \& Abrahams, P.W. 1981b. Soil ingestion as a pathway of metal intake into grazing livestock. In: Ernst, W.H.O. (ed.) Proceedings of the Third International Conference on Heavy Metals in the Environment. Amsterdam, September 1981. CEP Consultants, Edinburgh, 267-272.

Thornton, I. \& Aвrahams, P.W. 1983. Soil ingestion - a major pathway of heavy metals into livestock grazing contaminated land. The Science of the Total Environment, 28, 287-294.

Thornton, I. \& Abrahams, P.W. 1984. Historical record of metal pollution in the environment. In: Nriagu, J.O. (ed.) Changing Metal Cycles and Human Health: Report of the Dablem Workshop on Changing Metal Cycles and Human Health, Berlin, 1983, March 20-25. Life Sciences Research Report, 28. Springer-Verlag, Berlin, 7-25.

Thornton, I. \& Alloway, B.J. 1974. Geochemical aspects of the soil-plantanimal relationship in the development of trace element deficiency and excess. Proceedings of the Nutritional Society, 33, 257-266.

Thornton, I. \& Culbard, E. 1985. Metals in Urban Dusts and Soils. Environmental Technology Letters, 6, 137-144.

Thornton, I. \& Culbard, E. (eds). 1987. Lead in the home environment. Proceedings of the 4th European Meeting of the Society for Environmental Geochemistry and Health, 17-18 April 1986, Imperial College, London. Science Reviews, London.

Thornton, I. \& Howarth, R.J. (eds) 1986. Applied Geochemistry in the 1980s. Graham \& Trotman, London.

Thornton, I. \& Kinniburgh, D.G. 1978. Intake of lead, copper and zinc by cattle from soil and pasture. In: Kirchgessner, M. (ed.) Trace element metabolism in man and animals 3. Proceedings of Symposium., Munich, July 1977. Institut Fur Ernahrunesphysiologie Technische Universitat München, Freising-Weihenstephen, 499.

Thornton, I. \& Plant, J.A. 1980. Regional geochemical mapping and health in the United Kingdom. Journal of the Geological Society, London, 137, 575-586.

Thornton, I. \& WebB, J.S. 1967. Some aspects of geochemical reconnais sance in agriculture in North Wales. Report of the Welsh Soils Discussion Group, 9, 57-59

Thornton, I. \& Webb, J.S. 1970a. Regional geochemical reconnaissance and trace element mapping for agriculture. Journal of the Indian Society of Soil Science, 18, 357-365.

Thornton, I. \& Webb, J.S. 1970b. Geochemical reconnaissance and the detection of trace element disorders in animals. In: Mills, C.F. (ed.) Trace element metabolism in animals. Proceedings of WAAP/IBP Symposium, Livingstone, Edinburgh and London, 397-407.

Thornton, I. \& WebB, J.S. 1974. Environmental geochemistry: some recent studies in the United Kingdom. In: Hemphill, D.D. (ed.) Trace Substances in Environmental Health VII. University of Missouri, Columbia, MS, 89-98.

Thornton, I. \& WebB, J.S. 1975a. Trace elements in soils and surface waters contaminated by past metalliferous mining in parts of England. In: Hemphill, D.D. (ed.) Trace Substances in Environmental Health IX. University of Missouri, Columbia, MS, 77-88.

Thornton, I. \& WebB, J.S. 1975b. Distribution and origin of copper deficient and molybdeniferous soils in the United Kingdom. Proceedings of the copper in farming Symposium. Copper Development Association, Potters Bar, 3-21.

Thornton, I. \& WebB, J.S. 1977a. Application in the water industry of regional geochemical maps of England and Wales. Journal of the Institution of Water Engineers and Scientists, 31, 11-25.

Thornton, I. \& WebB, J.S. 1977b. The present status of environmental geochemistry and health in the United Kingdom. In: Hemphill, D.D. (ed.) Trace Substances in Environmental Health XI. University of Missouri, Columbia, MS, 81-88.

Thornton, I. \& WebB, J.S. 1979a. Geochemistry and health in the United Kingdom. Philosophical Transactions of the Royal Society, B288, 151-168.

Thornton, I. \& Webb, J.S. 1979b. Aspects of geochemistry and health in the United Kingdom. In: Ahrens, L.H. (ed.) Origin and distribution of the elements. Physics and Chemistry of the Earth, 11. Pergamon Press, Oxford, 791-817.

Thornton, I. \& WebB, J.S. 1980a. Trace elements in soils and plants. In: Blaxter, K. (ed.) Food chains and buman nutrition. Applied Science Publishers, Barking, 273-312.

Thornton, I. \& Webs, J.S. 1980b. Regional distribution of trace element problems in Great Britain. In: Davies, B.E. (ed.) Applied Soil Trace Elements. Wiley, London, 381-439.

Thornton, I., Atrinson, W.J., Webb, J.S. \& Poole, D.B.R. 1966. Geochemi$\mathrm{cal}$ reconnaissance and bovine hypocuprosis in Co. Limerick, Ireland. Irish Journal of Agricultural Research, 5, 280-283.

Thornton, I., Moon, R.N.B. \& Webb, J.S. 1969. Geochemical reconnaissance of the Lower Lias. Nature, London, 221, 457-459.
Thornton, I., Kershaw, G.F. \& Davies, M.K. 1972a. An investigation into sub-clinical copper deficiency in cattle. Veterinary Record, 90, 11-12.

Thornton, I., Kershaw, G.F. \& Davies, M.K. 1972b. An investigation into copper deficiency in cattle in the Southern Pennines. I. Identification of suspect areas using geochemical reconnaissance followed by blood copper surveys. Journal of Agricultural Science, Cambridge, 78, 157-164.

Thornton, I., Kershaw, G.F. \& Davies, M.K. 1972c. An investigation into copper deficiency in cattle in the Southern Pennines. II. Response to copper supplementation. Journal of Agricultural Science, Cambridge, 78, 165171

Thornton, I., Watling, H. \& Darracott, A. 1975. Geochemical studies in several rivers and estuaries used for oyster rearing. The Science of the Total Environment, 4, 325-345.

Thornton, I., Abrahams, P. \& Mattrhew, S.H. 1979. Some examples of the environmental significance of heavy metal anomalies disclosed by the Wolfson geochemical Atlas of England and Wales. Proceedings of the Second International Conference on the Management and Control of Heavy Metals in the Environment, London. CEP Consultants, Edinburgh, 218-221.

Thornton, I., John, S., Moorcroft, S., Watt, J., Strehlow, C.D., Barltrop, D. \& Wells, J. 1980. Cadmium at Shipham - A unique example of environmental geochemistry and health. In: Hemphill, D.D. (ed.) Trace Substances in Environmental Health XIV. University of Missouri, Columbia, MS, 27-37.

Thornton, I., Kinniburgh, D.G., Pullen, G. \& Smith, C.A. 1983. Geochemical aspects of selenium in British soils and implications to animal health. In: Hemphill, D.D. (ed.) Trace Substances and Environmental Health XVII. University of Missouri, Columbia, USA, 391-398.

Thornton, I., Culbard, E., Moorcroft, S., Watt, J., Wheatley, M., Thompson, M. \& Thomas, J.F.A. 1985. Metals in urban dusts and soils. Environmental Technology Letters, 6, 137-144.

Thornton, I., Abrahams, P.W., Culbard, E., Rother, J.A.P. \& Olson, B.H. 1986. The interaction between geochemical and pollutant metal sources in the environment: Implications for the community. In: Thornton, I. \& Howarth, R.J. (eds) Applied geochemistry in the 1980s. Graham \& Trotman, London, 270-308.

Thoresby, P. \& Thornton, I. 1979. Heavy metals and arsenic in soil, pasture herbage and barley in some mineralised areas in Britain: significance to animal and human health. In: Hemphill, D.D. (ed.) Trace Substances in Environmental Health XIII. University of Missouri, Columbia, MS, 77-88.

Todd, J.R., Diplock, A.T., Thornton, I., \& Williams, R.J.P. 1981. Metabolic and functional defects in selenium deficiency [Discussion]. Philisophical Transactions of the Royal Society, London, B294, 116-117.

Tooms, J.S. 1955. Geochemical prospecting. The Royal School of Mines Journal, 4, $7-13$.

Tooms, J.S. 1959. Field performance of some analytical methods used in geochemical prospecting. Congreso Geologico Internacional. Xxa Sesión, Cuidad de México, 1956. Symposium de Exploracion Geoquimica (Segundo Tomo), 377-388.

Tooms, J.S. 1961. Geochemical prospecting investigations in the Northern Rhodesian Copperbelt. Economic Geology, 56, 815-846.

Tooms, J.S. 1967 a. Problems in geochemical prospecting for base metals in tropical terrain. Inter-regional seminar on geochemical methods for mineral exploration for U.N. fellows from Asia, Africa, Latin America, and some countries of Europe. Moscow, August 1965.

Tooms, J.S. $1967 \mathrm{~b}$. Some investigations into the nature of trace elements in the zone of weathering. Inter-regional seminar on geochemical methods for mineral exploration for U.N. fellows from Asia, Africa, Latin America, and some countries of Europe. Moscow, August 1965

Tooms, J.S. $1967 c$. The inorganic mineral potential of the sea-floor. problems in its exploration. Proceedings of the British National Conference on the Technology of the Sea, Seabed held at the Atomic Energy Research Establishment., Harwell, April 5th, 6th., 7th, 1967; sponsored by the Ministry of Technology. United Kingdom Atomic Energy Authority (Research Group), Harwell, Didcot, Berks. Report AERE-R. 5500. Her Majesty's Stationery Office, London, Paper SB16, 1-20

Tooms, J.S. 1967d. Marine minerals in perspective. Hydrospace, 1, 40-46.

Tooms, J.S. 1968. Applied geochemistry in marine mineral exploration. Proceedings of the XXIIIrd International Geological Congress, Prague, 6, 107-122.

Tooms, J.S. 1970a. Metal deposits in the Red Sea - their nature, origin and economic worth. Underwater Science and Technology Journal, 2, 28-33.

Tоомs, J.S. 1970b. Review of knowledge of metalliferous brines and related deposits. Transactions of the Institution of Mining and Metallurgy, London, B79, 116-126 [Discussion, B80, 55, 294-295].

Tooms, J.S. $1970 c$. Some aspects of exploration for marine mineral deposits. In: Jones, M.J. (ed.) Mining and Petroleum Geology (Proceedings of the Ninth Commonwealth Mining and Metallurgical Congress, London, May 3-24, 1969). Institution of Mining and Metallurgy, London, 2, 285-301. 
Tooms, J.S. 1970d. Phosphatlagerstatten in Atlantik nordwestlich Afrikas. Umschan in Wissenschaft und Technik, 70/(9).

Tooms, J.S. 1972. Potentially exploitable marine minerals. Endeavour, 31, 113-117.

Tooms, J.S. \& JAY, J.R. 1964. The role of the biochemical cycle in the development of copper/cobalt anomalies in the freely drained soils of the Northern Rhodesian Copperbelt. Economic Geology, 59, 826-834.

Tooms, J.S. \& Kaewbaidhoon, S. 1961. Dispersion of tin in soil over mineralization at Sungei Lembing, Malaya. Transactions of the Institution of Mining and Metallurgy, 70, 475-490 [Discussion, 70, 614-622].

Tooms, J.S. \& Rugheim, M. 1969. Additional metalliferous sediments in the Red Sea. Nature, London, 223, 1356-1359.

Tooms, J.S. \& Summerhayes, C.P. 1968. Phosphatic rocks from the Northwest African Continental Shelf. Nature, London, 218, 1241-1242.

Tоомs, J.S. \& Weвв, J.S. 1961. Geochemical prospecting investigations in the Northern Rhodesian Copperbelt. Economic Geology, 56, 815-846.

Tooms, J.S., Elliott, I. \& Mather, A.L. 1965a. Secondary dispersion of molybdenum from mineralization, Sierra Leone. Economic Geology, 60, 1478-1496.

Tooms, J.S., Taylor Smith, D., Nichol, I., Ong, P. \& Wheildon, J. $1965 b$. Geochemical and geophysical mineral exploration experiments in Mount's Bay, Cornwall. In: Whittard, W.F. \& Bradshaw, R. (eds) Submarine Geology and Geophysics. Proceedings of the 17th Symposium of the Colston Research Society. Colston Research Papers 17. Butterworths Scientific Publications, London, 363-391.

Tooms, J.S., Summerhayes, C.P. \& Cronan, D.S. 1969. Geochemistry of marine phosphate and manganese deposits. Oceanography and Marine Biology. An Annual Review, 7, 49-100.

Tooms, J.S., Summerhayes, C.P. \& McMaster, R.L. 1971. Marine geological studies on the north-west African margin: Rabat-Dakar. In: Delany, F.M. (ed.) The geology of the East Atlantic continental margin. Institute of Geological Sciences Report, 70/(14), 9-25.

Tooms, J.S., Holmes, R. \& Horowitz, A. 1973. Confirmation of Ostapoff's fourth brine hole, Red Sea. Nature, London, 241, 161-162.

Troyer, L., Olson, B.H., Hill, D.C., Thornton, I. \& Matthews, I. 1980. Assessment of metal availability in soil through the evaluation of bacterial metal resistance. In: Hemphill, D.D. (ed.) Trace Substances in Environmental Health XIV. University of Missouri, Columbia, MS, 129-141.

Troyer, L., Thornton, I. \& Olson, B.L. 1981. Evaluation of cadmium pollution in British soils by natural bacterial populations. Developments in Industrial Microbiology, 22, 537-542.

VARnavas, S.P. \& Cronan, D.S. 1981. Partition geochemistry of sediments from DSDP 424 in the Galapagos hydrothermal mounds field. Mineralogical Magazine, 44, 325-331.

Varnavas, S.P. \& Cronan, D.S. 1988. Arsenic, antimony and bismuth in sediments and waters from the Santorini hydrothermal field, Greece. Chemical Geology, 67, 295-305.

Walker, P.B. \& Tooms, J.S. 1963. Secondary dispersion of copper from the Karang Lode, North Borneo. In: Fiтch, F.H. (ed.) Proceedings of the First British Borneo Geological Conference, 1961. Held at the Geological Survey Office, Kuching, Sarawak 25 to 30 November 1961. Government Printing Office, Kuching. British Borneo Geological Survey Bulletin, 4, 91-118.

Watling, R.J., Davis, G.R. \& Meyer, W.T. 1973. Trace identification of mercury compounds as a guide to sulphide mineralization at Keele, Eire. In: JonES, M.J. (ed.) Geochemical Exploration 1972. Institution of Mining and Metallurgy, London, 59-69.

Watts, J. 1985. Industrial emissions monitoring - Area studies. Proceedings of National Society for Clean Air Workshop Towards Air Quality Management, 26-27 March, Warwick University. National Society for Clean Air, Brighton, 1-13.

WatTs, J. \& Johnson, D.L.J. 1987. Characterisation of dusts by scanning electron microscopy with energy dispersive $\mathrm{X}$-ray spectroscopy. In: Thornton, I. \& Culbard, E.B. (eds) Lead in the Home Environment. Proceedings of the 4th European Meeting of the Society for Environmental Geochemistry and Health, 17-18 April 1986, Imperial College, London. Science Reviews Limited, London. 85-96.

Watts, J., Moorcroft, S., Brooks, K., Culbard, E.B. \& Thornton, I. 1983. Metal contamination of dusts and soils in urban and rural households in the United Kingdom. 1. Sampling and analytical techniques for household and external dusts. In: Hemphill, D.D. (ed.) Trace Substances in Environmental Health - XVII, University of Missouri, Columbia, MS, 229-235.

Watтs, J.T., Tоомs, J.S. \& Weвb, J.S. 1963. Geochemical dispersion of niobium from pyrochlore-bearing carbonatites in Northern Rhodesia. Transactions of the Institution of Mining and Metallurgy, 72, 729-747 [Discussion, 73, 104-108; Authors' reply to discussion, 73, 432-433, 616-619].

Wевв, J.S. 1943. The columbite-tantalite suite, proposed nomenclature and specific identification. Unpublished report. Geological Survey of Nigeria.
Webв, J.S. 1946. A replacement "pegmatite" vein in the Carn Brea granite. Geological Magazine, 83, 177-185.

Weвв, J.S. 1947. The genesis of some micro-veinlets in Cornish grantiteporphyry. Geological Magazine, 84, 65-78.

Webв, J.S. 1953. A review of American progress in geochemical prospecting, and recommendations for future British work in this field. Transactions of the Institution of Mining and Metallurgy, 62, 321-348 [Discussion, 62, 456-463].

WeBв, J.S. 1954. A brief review of geochemical prospecting excluding analytical aspects. Paris, 29 June 1954. Organisation for European Economic Co-operation. European Productivity Agency. Paris. Report no. EPA/ST/879.

Webi, J.S. 1958a. Observations on the geology and the origin of the San Domingos pyrite deposit, Portugal. Comunicadoes dos Services Geologicos de Portugal, 42, 129-145.

Webs, J.S. 1958b. Observations on geochemical exploration in tropical terrains. Report of the 20th International Geological Congress, Mexico City. 1956. Symposium on Geochemical Exploration. 1, 143-173.

WebB, J.S. 1959. Notes on geochemical prospecting for lead-zinc deposits in the British Isles. The future of non-ferrous mining in Great Britain and Ireland. Proceedings of a symposium arranged by the Institution of Mining and Metallurgy in collaboration with the United Kingdom Metal Mining Association, held on 23rd and 24th September, 1958, at the Federation of British Industries. Institution of Mining and Metallurgy. London, 23-40 [Discussion, 472-473].

Webb, J.S. 1964. Geochemistry and life. New Scientist, 23, 504-507.

Webi, J.S. 1966. Memorandum Concerning Proposal for Geochemical Atlas of Ireland. Unpublished Applied Geochemistry Research Group memorandum, 12 August 1966; revised 31 March 1967. 5 pp.

Weвв, J.S. 1969. Geochemical reconnaissance and medical geography. Engineering and physical science applied to medicine and the biomedical sciences. Imperial College of Science and Technology, London, 43-45.

Weвb, J.S. 1970. Some geological applications of regional geochemical reconnaissance. Proceedings of the Geologists' Association, 81, 585-594.

Wевв, J.S. 1971. Regional geochemical reconnaissance in medical geography. In: CANNON, H.L. \& Hopps, H.C. (eds) Environmental geochemistry in bealth and disease. Proceedings of an American Association for the Advancement of Science Symposium, Dallas, Texas, December 1968. Memoir 123. Geological Society of America, Boulder, Colorado, 31-42.

Webi, J.S. 1973. Applied geochemistry and the community. [Presidential address delivered on 17 May 1973]. Transactions of the Institution of Mining and Metallurgy, A82, 23-28.

Weвв, J.S. 1975. Environmental problems and the exploration geochemist. [Keynote address]. In: Elliott, I.L. \& Fletcher, W.K. (eds) Geochemical Exploration 1974. Elsevier, Amsterdam, 5-17.

Webi, J.S. 1979. The Wolfson Geochemical Atlas of England and Wales. Topic [Newsletter of the Imperial College of Science and Technology, London], no. 5.8, 19 February 1979, 4-6.

Webb, J.S. \& AtKinson, W.J. 1965. Regional geochemical reconnaissance applied to some agricultural problems in Co. Limerick, Eire. Nature, London, 208, 1056-1059.

Webb, J.S. \& Howarth, R.J. 1979. Regional geochemical mapping. Philosophical Transactions of the Royal Society, London, B288, 81-93.

Webb, J.S. \& Lakin, H.W. 1954. Une nouvelle technique de prospection des gîtes métallifères: La géochimie. [Editorial summary of lacture] L'Écho des Mines et de la Métallurgie, Paris, 321-324, 397-399.

Webb, J.S. \& Millman, A.P. 1950. Heavy minerals in natural waters as a guide to ore: a preliminary investigation in West Africa. Transactions of the Institution of Mining and Metallurgy, 59, 323-336 [Discussion, 59, 336-346; Authors' reply to discussion: 59, 346-349].

Webb, J.S. \& Millman, A.P. 1951. Heavy minerals in vegetation as a guide to ore: a biogeochemical reconnaissance in West Africa. Transactions of the Institution of Mining and Metallurgy, 60, 473-504.

Webв, J.S. \& Thompson, M. 1977. Analytical requirements in exploration geochemistry. Pure and Applied Chemistry, 49, 1507-1518.

WebB, J.S. \& Thornton, I. 1965. The agricultural significance of regional geochemical reconnaissance in the United Kingdom. Agricultural Advisory Council Report AAC 75.

Webi, J.S. \& Thornton, I. 1971a. The application of regional geochemistry in agriculture. Mineral studies with isotopes in domestic animals. Proceedings of a panel on the use of nuclear techniques in studies of mineral metabolism and disease in domestic animals organised by the joint FAO/LAEA Division of Atomic Energy in Food and Agriculture beld in Vienna on 28th September-2nd October 1970. International Atomic Energy Agency, Vienna, 189-191.

Webb, J.S. \& Thornton, I. 1971b. Agricultural applications of regional geochemical reconnaissance. State Veterinary Journal, 26, 165-174.

Webi, J.S., Toоms, J.S. \& Gilbert, M.A. 1959. Geochemical drainage reconnaissance for copper in N. Rhodesia. Transactions of the Institution of 
Mining and Metallurgy, 68, 125-144 [Discussion, 68, 321-334; 68, 459-460; Authors' reply to discussion, 69, 114-117].

Webb, J.S., Baker, M.D. \& Rickard, M. 1963. Geochemical anomalies in the coastal environment of Vanua Levu, Fiji. The Mining Magazine, 109, 329-336.

Webb, J.S., Fortescue, J.A.C., Nichol, I. \& Tooms, J.S. 1964a. Regional geochemical maps of the Namwala Concession Area Zambia based on a reconnaissance stream sediment survey. Geological Survey of Zambia, Lusaka [11 sheets].

Webb, J.S., Fortescue, J.A.C., Nichol, I. \& Tooms, J.S. 1964b. Regional geochemical reconnaissance in the Namwala Concession Area Zambia. To accompany the Geochemical maps of the Namwala Concessiona Area published by the Geological Survey of Zambia in 1964. Technical Communication, 47. Geochemical Prospecting Research Centre, Imperial College of Science and Technology, London.

Webb, J.S., Thornton, I. \& Fletcher, W.K. 1966. Seleniferous soils in parts of England and Wales. Nature, London, 211, 327.

Webb, J.S., Thornton, I. \& Fletcher, W.K. 1968a. Geochemical reconnaissance and hypocuprosis. Nature, London, 217, 1010-1012.

Webb, J.S., Nichol, I. \& Thornton, I. 1968b. The broadening scope of regional geochemical reconnaissance. Proceedings of the XXIIIrd International Geological Congress, Prague, 6, 131-147.

Webi, J.S., Thornton, I. \& Nichol, I. 1971. The agricultural significance of regional geochemical reconnaissance in the United Kingdom. Trace elements in soils and crops. Ministry of Agriculture Fisheries and Food Technical Bulletin, 21, 1-7.

Webb, J.S., Nichol, I., Foster, R., Lowenstein, P.L. \& Howarth, R.J. 1973. Provisional Geochemical Atlas of Northern Ireland. Technical Communication, 60. Applied Geochemistry Research Group, Imperial College of Science and Technology, London.

Webb, J.S., Thornton, I., Thompson, M., Howarth, R.J. \& Lowenstein, P.L. 1978. The Wolfson Geochemical Atlas of England and Wales. Clarendon Press of Oxford University Press, Oxford.

Webb, J.S., Thornton, I., Howarth, R.J. \& Thompson, M. 1979. The Wolfson Geochemical Atlas of England and Wales. Chemistry in Britain, 15, 500-505.

Williams, C. \& Thornton, I. 1972. The effect of soil additives on the uptake of molybdenum and selenium from soils from different environments. Plant and Soil, 36, 395-406.

Williams, C. \& Thornton, I. 1973. The use of soil extractants to estimate plant-available molybdenum and selenium in potentially toxic soils. Plant and Soil, 39, 149-159.

Williams, D. 1954. Geochemical Prospecting Research Centre at the Royal School of Mines, Imperial College of Science and Technology. Transactions of the Institution of Mining and Metallurgy, 64, 51-58.

Williams, D. 1960. Research in applied geochemistry at Imperial College, London. Report of the 20th International Geological Congress, Mexico City, 1956. Symposium on Geochemical Exploration, 3, 699-710.

Wood, G.A. 1959. A rapid method for the determination of small amounts of tin in soils. Report of the 20th International Geological Congress, Mexico City, 1956. Symposium on Geochemical Exploration, 2, 461-474.

Wood, G.A. \& Stanton, R.E. 1957. A rapid method for the determination of chromium in soils for use in geochemical prospecting. Transactions of the Institution of Mining and Metallurgy, 66, 331-340.

Woolf, D.L., Tooms, J.S. \& KIRK, H.J.C. 1966. Geochemical surveys in the Labuk Valley, Sabah, 1965. Borneo Region, Malaysia Geological Survey Annual Report for 1965. Government Printing Office, Kuching, Sarawak, 212-226.

Wuyi, W., van Dorst, S. \& Thornton, I. 1987. The selenium status of sheep in Britain as indicated by wool selenium concentration. Environmental Geochemistry and Health, 9, 48-51.

Xu, J. \& Thornton, I. 1985. Arsenic in garden soils and vegetable crops in Cornwall, England: Implications for human health. Environmental Geochemistry and Health, 7, 131-133.

YIM, W.W.S. 1979. Geochemical exploration for offshore tin deposits in Cornwall. Jones, M.J. (ed.) Proceedings of the 11th Commonwealth Mining and Metallurgical Congress, Hong Kong, 1978. Institution of Mining and Metallurgy, London, 67-77.

\section{Appendix 2. Technical Communications (abbreviated operating instructions for analytical methods) of the GPRC/AGRG, 1956-1973}

Note: nos. 6, 9, 12, 13,41, 47, 57, 58, 60, 61 are on non-analytical topics and are included in Appendix 1.

1. Stanton, R.E. \& Gilbert, M.A. 1956. Analytical procedures employed at the Geochemical Prospecting Research Centre at Imperial College, London. 1. Preliminary treatment of soil and sediment samples for analysis.
2. Stanton, R.E. \& Gilbert, M.A. [1956] Analytical procedures employed at the Geochemical Prospecting Research Centre at Imperial College, London. 2. Copper lead. zinc in soils sediments. rocks, by dithizone in carbon tetrachloride [After: Bloom H. Crowe H.E. 1953. U.S. Geological Survey Open File Report].

3. Stanton, R.E. \& Gilbert, M.A. 1956. Analytical procedures employed at the Geochemical Prospecting Research Centre at Imperial College, London. Arsenic in soils, sediments and rocks by a modified Gutzeit test [After: Almond, H. 1953. Field method for the determination of traces of arsenic in soils. Analytical Chemistry, 25, 1766-1767].

4. Stanton, R.E. \& Gilbert, M.A. 1956. Analytical procedures employed at the Geochemical Prospecting Research Centre at Imperial College, London. Copper, cobalt and nickel in soils, sediments and rocks by chromatography [After: Hunt E.C., North, A.A. \& Wells, R.A. 1955. The application of paper chromatographic methods of analysis to geochemical prospecting. Analyst, 80, 172-194].

5. Stanton, R.E. \& Gilbert, M.A. 1956. Chromium in soils, sediments and rocks by chromate and by diphenylcarbazide.

7. Wood, G.A. \& STANTON, R.E. 1956. A rapid method for the determination of chromium in soils for use in geochemical prospecting. [ $c$. Wood, G.A. \& Stanton, R.E. 1957. A rapid method for the determination of chromium in soils for use in geochemical prospecting. Transactions of the Institution of Mining and Metallurgy, 66, 331-340].

8. Holman, R.H.C. 1956. A method for determining soluble copper in soils and alluvium - introducing white spirit as a solvent for dithizone. [ $c f$. Holman, R.H.C. 1956. A method for determining readily soluble copper in soil and alluvium; introducing white spirit as a solvent for dithizone. Transactions of the Institution of Mining and Metallurgy, 66, 7-16].

10. StAnton, R.E. \& Gilbert, M.A. 1956. Analytical procedures employed at the Geochemical Prospecting Research Centre at Imperial College, London. 6. Molybdenum and tungsten in soils, sediments and rocks by dithiol. [Modified from North, A.A. n.d. Department of Scientific and Industrial Research Scientific Report CRL/AE 127. cf. North, A.A. 1956. Geochemical field methods for the determination of tungsten and molybdenum in soils. Analyst, 81, 660-668].

11. Wood, G.A. 1956. A rapid method for the determination of small amounts of tin in soil. [cf. Wood, G.A. 1959. A rapid method for the determination of small amounts of tin in soils. Congreso Geologico Internacional. XXe Sesión. Cuidad de México, 1956. Symposium de Exploracion Geoquimíca. II, 461-474].

14. Anon. 1958 [rev. 1960, 1961, 1965] Determination of cobalt in soil, sediment., rock samples. [Rev. after Stanton, R.E., McDonald, A.J. 1961. Field determination of cobalt in soil and sediment samples. Transactions of the Institution of Mining and Metallurgy, London, 71, 511-516].

15. ANON. 1960 [rev. 1962, 1965, 1967]. Determination of molybdenum in soil, sediment., rock samples. [After: North A.A. 1956. Geochemical field methods for the determination of tungsten and molybdenum in soils. Analyst, 81, 660-668; Marshall, N.J. 1964. Rapid determination of molybdenum in geochemical samples using dithiol. Economic Geology, 59, 142 148].

16. Anon. 1960 [rev. 1962, 1964]. Determination of lead in soil, sediment and rock samples. [After: Bureau de Recherches Géologiques, Géophysiques et Minières 1957].

17. Anon. 1960 [rev. 1962, 1965]. Determination of antimony in soil, sediment. rock samples. [After: Stanton, R.E., McDonald, A.J., 1961, Field determination of antimony in soil., sediment, samples. Transactions of the Institution of Mining and Metallurgy, 71, 517-522; 1961. The spectrophotometric determination of antimony with Brilliant green. Analyst, 87, 299-301].

18. Anon. 1960 [rev. 1962, 1964, 1966]. Determination of tin in soils., sediments. [After: Stanton, R.E., McDonald, A.J. 1961. Field determination of tin in geochemical soil and stream sediment surveys. Transactions of the Institution of Mining and Metallurgy, 71, 27-29; cf. McDonald, A.J. \& Stanton, R.E. 1962. The spectrophotometric determination of tin in soil with gallein. Analyst, 87, 600-602].

19. StAnton, R.E. 1962. The field determination of zinc with dithizone in the presence of aluminium. [cf. Stanton, R.E. and McDonald, A.J. 1963. Application of the AutoAnalyzer to the determination of zinc in soils and sediments. Analyst, 88, 608-613].

20. Anon. 1962. Determination of arsenic in soil, sediment and rock samples. [After: Almond, H. 1953. Field method for the determination of traces of arsenic in soils. Analytical Chemistry, 25, 1766-1767].

21. Anon. 1962 [rev. 1965]. Determination of cold-extractable heavy metals in sediment samples. [After: Bloom, H., 1955. A field method for the determination of ammonium citrate-soluble heavy metals in soils and alluvium. Economic Geology, 50, 533-541]. 
22. ANON. 1959 [rev. 1961, 1965]. Determination of beryllium in soil, sediment and rock samples. [After: Hunt, E.C., Stanton, R.E. \& Wells, R.A.1960. Field determination of beryllium in soils for geochemical prospecting. Transactions of the Institution of Mining and Metallurgy, London, 69, 361-369.]

23. ANON. 1961 [1962; rev. 1964]. Determination of copper with 2,2'diquinolyl in soil, sediment samples. [After: Almond, H. 1955. Rapid field and laboratory method for the determination of copper in soil and rock. U.S. Geological Survey Bulletin, 1036-A, 1-8].

24. Anon. 1957 [1960; rev. 1962, 1965]. Determination of copper with dithizone in soil., sediment samples. [After: Bloom, H., Crowe, H.E. 1953. U.S. Geological Survey Open File Report].

25. AnON. 1960 [rev.1962]. Determination of cold-extractable copper in soil, sediment samples. [After: Holman, R.H.C. 1956. A method for determining readily-soluble copper in soil and alluvium - Introducing white spirit for dithizone. Transactions of the Institution of Mining and Metallurgy, 66, 7-16].

26. ANON. 1960 [1962, rev. 1965, 1967]. Determination of carbonate., bicarbonate in natural water. [After: Scott, N.W. 1955. Standard methods of chemical analysis. (5th ed.) The Technical Press, London, II, 2095].

27. ANon. 1960 [1962]. Determination of sulphate in natural water. [After: Scott, N.W. 1955. Standard methods of chemical analysis. 5th ed. The Technical Press, London, II, 2091].

28. ANON. 1962 [rev. 1965]. Determination of nickel in soil, sediment samples. [After: Stanton, R.E., Coope, J. 1958. Modified field test for the determination of small amounts of nickel in soils and rocks. Transactions of the Institution of Mining and Metallurgy, 68, 9-14].

29. Anon. 1960 [rev. 1962, 1966]. Determination of chloride in natural water. [After: Anonymous. 1956. British Standard 2690. Methods of testing water used in industry. British Standards Institution, London, 50.]

30. Anon. 1960 [rev. 1962, 1965]. Determination of zinc in soil, sediment and rock samples. [After: Stanton, R.E. 1962. Technical Communication 19, G.P.R.C., Imperial College London].

31. ANON. 1960 [1962; rev. 1965]. Determination of cold-extractable zinc in soil and sediment samples. [Adapted from: Holman, R.H.C. 1956. A method for determining readily-soluble copper in soil and alluvium Introducing white spirit for dithizone. Transactions of the Institution of Mining and Metallurgy, 66, 7-16].

32. ANON. 1962 [rev. 1965, 1967]. Determination of organic carbon in soil and sediment samples. [After: Schollenberger, C.J. 1927. A rapid approximate method for determining soils organic matter. Soil Science, 24, 65-68].

33. Anon. 1962 [rev. 1965]. Determination of sulphate in soil and sediment samples. [After: Scott, N.W. 1955. Standard methods of chemical analysis. (5th ed.) The Technical Press, London, II, 2091].

34. Anon. 1962 [rev. 1965]. Preparation of soil and sediment samples for analysis. [After: Stanton, R.E. \& Gilbert, M.A. 1956. Technical Communication, 1, G.P.R.C., Imperial College London].

35. ANON. 1962 [rev. 1965]. Determination of chromium in soil, sediment and rock samples. [After: Wood, G.A. \& Stanton, R.E. 1957. A rapid method for the determination of chromium in soils for use in geochemical prospecting. Transactions of the Institution of Mining and Metallurgy, 66, 331-340].

36. ANON. 1960 [1962; rev. 1965]. Determination of manganese in soil and sediment samples. [After: Almond, H. 1953. A field method for the determination of manganese in soils adapted from methods described in the literature. U.S. Geological Survey Open File Report].

37. ANON. 1962 [rev. 1965]. Determination of tungsten in soil, sediment and rock samples. [After: North, A.A. 1956. Geochemical field methods for the determination of tungsten and molybdenum in soils. Analyst, 81, 660-668]

38. Anon. n.d. [1962; rev. 1965]. Separation of cobalt, copper, lead, nickel and zinc from soil sediments and silicate rocks after decomposition with hydrofluoric acid. [After: Stanton, R.E., McDonald, A.J. and Carmichael, I. 1962. The determination of some trace elements in silicate rocks. The Analyst, 87, 134-39].

39. AnON. 1962 Determination of potassium in soil, sediment and rock samples. [After: Carmichael, I.S.E. 1962. Methods for the analysis of silicate rocks. Part I. Imperial College of Science and Technology, London].

40. Anon. [Stanton, R.E.]. 1960 [rev. 1962]. Determination of iron in soil and sediment samples. [Adapted from: Sandell, E.B. 1959. Colorimetric determination of traces of metals. 3rd ed. Interscience Publishers, New York and London].

42. ANON. 1962 [rev. 1965]. Determination of niobium in soil, sediment and rock samples. [After: Hunt, E.C., North, A.A. \& Wells, R.A. 1955. Application of paper chromatographic methods of analysis to geochemical prospecting. Analyst, 80, 172-194].

43. Anon. 1962 [rev. 1965]. Determination of uranium in soil and sediment samples. [After: Grimaldi, F.S., May, I. \& Fletcher, M.H. 1952. U.S.
Geological Survey fluorimetric methods of uranium analysis. U.S. Geological Survey Circular, 199].

44. Anon. 1962 [rev. 1967]. Determination of uranium in natural water samples. [After: Ostle, D. 1954. Geochemical prospecting for uranium. Mineralogical Magazine, 140, 201-208].

45. ANON. 1963 [rev.1966]. The determination of cold-extractable arsenic in soil and sediment samples. [After: James, C.H. 1957. Technical Communication 12, G.P.R.C., Imperial College, London].

46. Anon. 1963. The statistical control of routine analysis. [After: Craven, C.A.U. 1954. Statistical estimation of the accuracy of assaying. Transactions of the Institution of Mining and Metallurgy, 63, 551-563].

48. ANON. 1965. The determination of gold in soil and sediment samples. [After: Stanton, R.E. \& McDonald, A.J. 1964. The determination of gold in soil with Brilliant green. Analyst, 89, 767-770].

49. ANON. 1965. The determination of arsenic in soil and sediment samples. [After: Stanton, R.E. 1964. The field determination of arsenic in soils and sediments. Economic Geology, 59, 1599-1602].

50. Anon. 1964 [rev. 1965]. Decomposition of samples with nitric and perchloric acid. [After: Stanton, R.E. \& McDonald, A.J. 1964. The determination of gold in soil with Brilliant green. Analyst, 89, 767-770].

51. ANON. 1965. Determination of selenium in soils and sediments. [After: Stanton, R.E. \& McDonald, A.J. 1965. The determination of selenium in soils and sediments with 3,3'-diaminobenzidine. The Analyst, 90, 497-499].

52. AnON. 1966. Determination of phosphorous in soil, sediment and rock samples. [After: Ward, F.N., Lakin, H.W., Canney, F.C. et al. 1963. Analytical methods used in geochemical exploration by the U.S. Geological Survey. U.S. Geological Survey Bulletin, 1152, 66].

53. ANON. 1962 [1966]. Determination of carbonate in soil samples.

54. ANON. 1967. The determination of boron in soils, sediments and rocks. [After: Stanton, R.E. \& McDonald, A.J. 1966. The colorimetric determination of boron in soils, sediments and rocks with Methylene blue. Analyst, 91, 775-778].

55. AnON. 1967. Abbreviated operating instructions for the A.G.R.G. mercury vapour meter [After: James, C.H. \& Webb, J.S. 1964. Sensitive mercury vapour meter for use in geochemical prospecting. Transactions of the Institution of Mining and Metallurgy, London, 73, 633-641].

56. ANON. 1967. The determination of molybdenum in soil and sediment samples. [After: Stanton, R.E. \& Hardwick, A.J. 1967. The colorimetric determination of molybdenum in soils and sediments by zinc dithiol. Analyst, 92, 387-390].

57. Anon. [Thompson, M.]. 1973. Users guide to System C. A brief description and provisional specification of a rapid computerised direct reading spectrographic technique.

\section{Appendix 3. GPRC and AGRG thesis topics, 1951-1988}

Notes: Unless otherwise indicated, all the theses listed here were written by students of the Department of Geology: DIC, Diploma of Imperial College; PhD, MPhil and MSc theses are submitted for University of London degrees (in many cases these were also submitted for the DIC). CC, Computing and Control; CS, Computing Science; ET, Environmental Technology; G, Geology; IC, Inorganic chemistry; MG, Mining Geology; S, Statistics. Name of supervisor(s) in parentheses.

Abrahams, Peter William. 1983. Distribution, dispersion and agricultural significance of metals in soils of the mining regions of south west England. PhD (Thornton).

Aguilar [Ravello], Alfonso Nemesio. 1974. The regional geochemical distribution of arsenic in south west England. $\mathrm{PhD}$ (Lowenstein).

Ahmed, Adley Abdel Mageed. 1968. Geochemical and mineralogical studies of sediments from the south-west African Shelf. MPhil (Tooms).

Anderson, Robert Keith. 1986. Preconcentration and speciation techniques for the analyses of metals in natural waters. $\mathrm{PhD}$ (Thornton).

Aplin, Andrew Cameron. 1983. Geochemistry and environment of deposition of some ferromanganese oxide deposits from the south equatorial Pacific. PhD (Cronan).

Arias Farias, Jaime Alfredo. 1979. The application of selected vapour geochemistry techniques to prospecting for concealed mineralization in Northern Chile. $\mathrm{PhD}(\mathrm{Hale}$ \& Lovell).

Armour-Brown, Ashlyn. 1971. Provincial and regional geochemical studies in Zambia. $\mathrm{PhD}$ (Nichol \& Howarth).

Arnórsson, Stefán. 1969. A geochemical study of selected elements in thermal waters of Iceland. $\mathrm{PhD}$ (Tooms).

AtKinson, Warren John. 1967. Regional geochemical studies in County Limerick, Ireland, with particular reference to selenium and molybdenum. $\mathrm{PhD}$ (Webb). 
Bailey, Ian Frederick. 1980. The use of advanced analytical techniques for multi-element analysis of water. MSc [ET] (Thornton).

Band, Raymond Brian. 1969. Dispersion of nickel and molybdenum from mineralization in glaciated terrain, $S$. Norway. $\mathrm{PhD}$ (Bradshaw).

Bee, Alastair George. 1974. The marine geochemistry and geology of the Atlantic continental shelf of central Morocco. $\mathrm{PhD}$ (Cronan).

Bignell, Roger Douglas. 1975. The geochemistry of metalliferous brine precipitates and other sediments from the Red Sea. PhD (Cronan).

Bird, Cherry Elizabeth. 1981. A study of the remobilization of heavy metals and arsenic from a spoil heap in Cornwall. MSc [ET] (Thornton).

Booth, LesLie Gardner. 1979. The physical and chemical dispersion of tin. MSc [MG] (C. J. Dixon; MG).

Boyle, Daniel Robert. 1976. The geochemistry of fluorine and its applications in mineral exploration. $\mathrm{PhD}$ (Webb).

Brabec, Dragan. 1964. Geochemical prospecting studies in Bunmabon district, Co. Waterford, Ireland; and Gornja Lipa area, East Serbia, Yugoslavia. DIC (James \& Tooms).

Brebner, Jocelyn. 1987. The role of soil ingestion in the trace element nutrition of grazing livestock. PhD (Thornton).

Brown, Alastair Gordon. 1970. Dispersion of copper and associated trace elements in a Kalahari sand environment, North-west Zambia. $\mathrm{PhD}$ (Tooms).

Brown, Christopher John. 1983. Geology, geochemistry and economic significance of the celestite deposits of Avon. PhD (Howarth).

Butt, Charles Ray Morton. 1971. The influence of environment on regional geochemical patterns in Northern Ireland. $\mathrm{PhD}$ (Nichol \& Thornton).

Byman, Jan Erik Gustav. 1978. Investigation of sulphur vapour techniques in exploration geochemistry. MPhil (Webb \& Lovell).

Çă̆atay, Memet Namick. 1977. Development of geochemical exploration techniques for massive sulphide ore deposits, Eastern Black Sea region, Turkey. $\mathrm{PhD}$ (Boyle \& Meyer).

Campain, Richard Phillips. 1981. Lithogeochemistry in relation to the lead-zino deposits of Mendip, Somerset. DIC (Howarth).

Castillo-Muñoz, Rolando. 1973. Application of discrimant and cluster analysis to regional geochemical surveys. $\mathrm{PhD}$ (Howarth).

Clews, Dirk Richard. 1962. The secondary dispersion of copper in the drainage system of the Kilembe Mine area, Uganda. PhD (Webb).

Colbourn, Philip. 1976. The application of geochemical reconnaissance data to trace metal pollution in agriculture. $\mathrm{PhD}$ (Thornton \& Alloway).

Cole, Thomas George. 1984. Mineralogy and geochemistry of metalliferous sediments from the Bauer Deep, S.E. Pacific and Atlantis II Deep, Red Sea. PhD (Cronan \& Dr. H. Shaw $[G])$.

Coles, Robin Steven. 1979. Runoff influences on beavy metal content of Hope Brook, Salop. MSc [ET] (Dr. G. R. Conway; ET).

Colley, Nicholas Martin. 1981. The geochemistry of ferromanganese oxide deposits and pelagic sediments of the north-west Indian Ocean. PhD (Cronan).

Coope, John Alan. 1958. Studies in geochemical prospecting for nickel in Bechuanaland and Tanganyika. PhD (Webb \& Tooms).

Corneil, Ernest Ray. 1960. Automatic colour determination, with special reference to the analysis of soils. $\mathrm{PhD}$ (Prof. A. Porter).

Coward, Richard NeIL. 1986. A statistical appraisal of regional geochemical data from the south-west Pacific for mineral exploration. PhD (Cronan).

Crisp, David Alan. 1975. Application of multivariate methods to regional geochemistry: the evaluation of a new technique. MSc [MG] (Howarth).

Cronan, David Spencer. 1967. The geochemistry of some manganese nodules and associated pelagic deposits. $\mathrm{PhD}$ (Tooms).

Cruzat Ossa, Alfredo Camilio Emilio. 1974. Application of regional stream sediment geochemistry in forecasting base metal production, northern England. $\mathrm{PhD}$ (Meyer).

Davie, Robert Franklin. 1976. A review of exploration geochemistry in the Canadian Shield. MSc [MG]. (?)

Davies, Philip Rhys. 1983. Geochemical application of ridge regression for tinmineralized granitoids. MSc [MG] (Howarth).

Davies, William Cameron. 1971. Regional geochemistry of stream sediments derived from an area underlain by the English Permo-Trias. PhD (Tooms \& Webb).

De Grys, Antionette Margaretha. 1959. Factors affecting the secondar geochemical dispersion of metals associated with sulphide mineralization [Isle of Man7. MSc [MG] (Webb, Tooms and Dr. S.E. Jacobs, Department of Bacteriology).

Debnam, Adrian Harry. 1961. Geochemical prospecting studies for beryllium in Central and East Africa. PhD (Webb).

Donovan, Peter Richard. 1965. Geochemical dispersion in relation to base metal deposits in glacial terrain in west-central Eire. PhD (James)

Dorbor, Jenkins KolObalie. 1985. Geochemical investigation of granitic rocks of Liberia. MPhil (Hale \& Howarth).

Duff, James Richard Valentine. 1975. Variability in some stream sediment geochemical data from Australia. $\mathrm{PhD}$ (Howarth).
Dunlop, Alistair Chisholm. 1973. Geochemical dispersion of tin in stream sediments and soils in south-west England. PhD. (Meyer).

Earle, Steven Alan Maxwell. 1983. Geological interpretation of the geochemistry of stream sediments, waters and soils in the Bristol district, with particular reference to the Mendip Hills, Somerset. PhD (Howarth).

El Shazley, El S.Mohamed. 1951. The application of the spectrographic analysis of minerals to the metallogenesis of lead-zinc ores. PhD [MG] (Webb).

El Zawahry, Mohamed Karam Allah Hassan. 1979. Sediment investigations in the Eastern Mediterranean Sea. PhD (Cronan).

Elderfield, Harry. 1970. Some geochemical aspects concerning oyster rearing at Conway, North Wales. DIC (Webb \& Thornton).

Elders, Joseph. 1972. A trace element distribution study with the stream sediments of the Lancefield District, Victoria, Australia. MSc [MG] (Prof. G.R. Davis \& B. Scott; MG).

Elliott, Ivor Llewellyn. 1962. Dispersion of arsenic and molybdenum in surface drainage, Sierra Leone. PhD (Webb, Mather \& Tooms).

Evans, David Stuart. 1972. Secondary dispersion of mercury and associated elements at Keele, Eire. $\mathrm{PhD}$ (Webb \& Meyer).

Fanta, Pablo. 1972. Effects of seasonal variations on the iron, manganese and associated metal contents of stream sediments and soils. MPhil (Lowenstein).

Fletcher, William Kenneth. 1968. Geochemical reconnaissance in relation to copper deficiency in livestock in the Southern Pennines and Devon. PhD (Webb, Thornton \& Nichol)

Fong, TAI LoON. 1975. Feature selection in multiclass pattern recognition. MSc [CC] (Howarth \& Dr. F. N. Parr [CC]).

Foo, Ban Nyen. 1979. A comparative study of the paragenesis, geochemistry and fluid inclusions of selected primary tin deposits of west Malaysia. PhD [MG] (C. Halls; MG).

Fortesque, John Adrian Claude. 1962. Some aspects of regional geochemical mapping in the southern province of Northern Rhodesia. DIC (Webb \& Tooms).

Gardner, Collins Ulrich Maximillian. 1980. The distribution of ten trace elements in rocks, soils and stream sedimenents in seven regions of England and Wales. $\mathrm{PhD}$ (Thornton).

Garrett, Robert Geoffrey. 1966. Regional geochemical reconnaissance of eastern Sierra Leone. PhD (Nichol).

Gladwell, David Robert. 1981. Research into geochemical exploration techniques for stanniferous mineralization. $\mathrm{PhD}$ (Hale).

Glasby, Geoffrey Philip. 1970. The geochemistry of manganese nodules and associated pelagic sediments from the Indian Ocean. $\mathrm{PhD}$ (Tooms).

Goodman, Jonathan Geoffrey. 1979. The dispersion of cadmium, lead and zinc in agricultural soils in the vicinity of old zinc mines at Shipham, Somerset. MSc [ET] (Thornton).

Govett, Gerald James Spurgeon. 1958. Geochemical prospecting studies in Northern Rhodesia. PhD (Webb \& Tooms).

Gregory, George Peter. 1970. Geochemical dispersion patterns related to kimber lite intrusives in North America. $\mathrm{PhD}$ (Tooms).

Guru, Sarweshwar. 1972. Geochemical studies in the South China Sea. DIC (Tooms).

Hale, Martin. 1978. Geochemical prospecting techniques for primary nickel ore in central Africa. PhD (Webb).

Harden, Geoffrey. 1962. Geochemical dispersion patterns and their relation to bedrock geology in the Nyawa area, N[orthern] Rhodesia. $\mathrm{PhD}$ (Tooms \& Webb).

Hazelhoff Roelfzema, Brundt Harm. 1968. Geochemical dispersion of tin in marine sediments, Mount's Bay, Cornwall. $\mathrm{PhD}$ (Tooms).

Hemans, David Austin. 1980. Geochemical methods in exploration. MSc [MG (C.J. Dixon; MG).

Hewlett, Geoffrey William. 1979. Selenium and tellurium - A review of the concentrations, geochemistry, economics and geology of some rare element enriched ores. MSc [MG] (C.J. Dixon; MG).

Higgo, Jennifer Joan Wynne. 1985. Radionuclide sorption by marine sediments. $\mathrm{PhD}$ (Cronan).

Holman, Ronald Herman Charles. 1956. Applied geochemical studies in Uganda and Sierra Leone. $\mathrm{PhD}$ (Webb).

Holmes, Richard. 1976. The regional distribution of cadmium in England and Wales. PhD (Howarth).

Horder, Michael Francis. 1979. Geochemical investigations of deep sea sediments from the Indian Ocean. PhD (Cronan).

Horowitz, Arthur Joseph. 1974. Geochemical investigations of sediments associated with the Mid-Atlantic Ridge. PhD (Cronan).

Horsnail, Richard Francis. 1968. The significance of some regional geochemical patterns in North Wales and South-west England. PhD (Webb, Thornton \& Nichol).

Hyde, Paul. 1981. An investigation of the heavy metal contamination of the Preston-under-Scar area, Wensleydale, North Yorkshire. MSc [ET] (Dr. G. R. Conway; ET). 
Jacobson, John Desmond. 1956. Trace element dispersion patterns related to mineralisation in Britain and Uganda. PhD [MG] (Webb).

James, Clifford Henry. 1957. Applied geochemical studies in Southern Rhodesia and Great Britain. $\mathrm{PhD}$ (Webb).

JAMES, LlOYd DAVID. 1965. Regional geochemical reconnaissance in the northern and southern sections of the Sula Mountains schist belt, Sierra Leone. PhD (Nichol \& Tooms).

Jay, John Raymond. 1959. Geochemical prospecting studies for cobalt and uranium in Northern Rhodesia. PhD (Webb \& Tooms).

Jensen, Robert Andrew. 1980. Geochemistry and removal of heavy metals in the River Hale, Cornwall. MSc [ET] (Dr. D.R. Conway).

Jnawali, Bharat Mani. 1979. Regional geochemical mapping and data interpretation in the lesser Himalayas of central Nepal. DIC (Hale \& Howarth).

Johnson, Carola Annette. 1984. The sources, dispersion and speciation of trace elements derived from acid mine drainage in the Carnon River and Restronguet Creek, Cornwall. PhD (Thornton).

Jones, David John William. 1975. Vapour phase geochemistry. MSc [MG] (Boyle).

Jones, Тімотну Hugh. 1982. The determination of heavy metal status of selected garden soils and vegetables. MSc [ET] (Thornton).

Jordan, William James. 1975. The application of regional geochemical reconnaissance to arable cropping in England and Wales. $\mathrm{PhD}$ (Thornton \& Alloway).

Jubeli, Youssed Maarouf. 1986. Multielement geochemical reconnaissance for uranium in the Palmyrides Region of central Syria. PhD (Hale \& Howarth).

Kaewbaidhoon, Sangob. 1961. Geochemical dispersion of tin in soils and stream sediments in Malaya. MSc [MG] (Webb \& Tooms).

Kagule-Magambo, James Emanuel. 1966, Studies of the association of copper and cobalt with major elements. DIC [MG] (Tooms).

Keeley, Helen Christine Maud. 1973. Cobalt, copper and manganese in relation to geochemical reconnaissance and agriculture. $\mathrm{PhD}$ (Thornton).

Kerbyson, John Donald. 1960. Application of spectrography to the study of secondary geochemical dispersion patterns related to mineral deposits in Africa and the Far East. PhD (Webb).

KhaleELeE, JefFrey. 1966. The application of statistics to areally distributed data in economic geology. MSc [MG] (C.J. Dixon).

KhaleELeE, JefFrey. 1969. The application of some data processing techniques in the interpretation of geochemical data. $\mathrm{PhD}$ (Nichol \& Howarth).

KöKsoy, MüмIn. 1967. Dispersion of mercury and other ore elements from mineral deposits in Turkey. PhD (Tooms \& Bradshaw).

Krank, Elizabeth Maria. 1958. Some rapid methods of determination of trace elements in soils and natural waters. MSc [IC] (?)

Larsson, Jan-Ola. 1970. Mineralogical and geochemical studies in areas of blanket peat in western Ireland. $\mathrm{PhD}$ (Nichol).

Leaman, Peter William. 1980. The use of geochemistry in uranium exploration. MSc [MG] (C.J. Dixon; MG).

Ledward, Richard ANTHONy. 1960. Geochemical prospecting studies for base metals in Tanganylea and Burma. PhD [MG] (Webb \& Tooms).

Lee, Jae Yeong. 1964. A discussion of the potential value of underwater mineral deposits and how they might be worked; and a review of factors controlling secondary chemical dispersion including their role in the planning and interpretation of geochemical prospecting survey; and the economic geology of Thailand and Indo-China. DIC [MG] (Tooms).

Leech, Anne Frances. 1984. The application of regional geochemistry in determining the causes and predicted incidence of bovine bypocupraemia. $\mathrm{PhD}$ (Thornton \& Howarth).

Leggo, Michael David. 1970. Further studies in mercury. DiC (Meyer).

Lovell, John Stanley. 1979. Applications of vapour geochemistry to mineral exploration. $\mathrm{PhD}$ (Webb).

Maley, Robert Lawrence. 1974. Recent advances in geochemical exploration techniques. MSc [MG] (Prof. G.R. Davis; MG).

Mancey, Steven John. 1980. Computer-based interpretation of large regional geochemical data sets. PhD (Howarth).

Mander, IAn PhiLip. 1981. An assessment of the sources of error in a bydrogeochemical survey of the Carnon River, Cornwall. MSc [ET] (Prof. G.R. Conway; ET).

Mantzos, Leonidas Achilles. 1982. Hydrothermal alteration studies and lithogeochemistry in the exploration for exhalative sulphide deposits. MSc [MG] (Hale).

Marples, Alan Edwin. 1979. The occurrence and behaviour of cadmium in soils and its uptake by pasture grasses in industrially contaminated and naturally metal-rich environments. $\mathrm{PhD}$ (Thornton).

Mather, Alfred Lewis. 1959. Geochemical prospecting studies in Sierra Leone. $\mathrm{PhD}$ (Prof. Williams, MG; \& Webb).

Matthews, Hilary. 1982. The distribution of cadmium and associated elements in the soil-plant system at sites in Britain contaminated by mining, smelting and metal-rich bedrock. $\mathrm{PhD}$ (Thornton).
Maurice, Yvon Théodore. 1973. Geochemical interpretation of base metal enrichment in soils overlying Lower Carboniferous rocks near Dalngean, County Offaly, Eire. $\mathrm{PhD}$ (Meyer).

Mazzucchelli, Richard Harold. 1965. Geochemical dispersion related to gold mineralization, Western Australia. PhD (Webb, Tooms \& James).

McArthur, John Malcolm. 1974. The geochemistry of phosphorite concretions from the Continental Shelf off Morocco. PhD (Tooms).

Mehrtens, Michael Brian. 1966. Geochemical dispersion from base metal mineralization, central Norway. $\mathrm{PhD}$ (Tooms).

Metcalfe, Anne Penelope. 1983. The mobilisation and dispersion of some heavy metals by surface drainage in three areas of past mining activity in England. $\mathrm{PhD}$ (Thornton).

Meyer, William Timothy Wakeford. 1973. Development and application of thermally-evolved vapour analysis in exploration geochemistry. $\mathrm{PhD}$ (Tooms, Webb \& Visiting Prof. A.R. Barringer).

Mill, Andrew John Bishop. 1977. Geochemical studies on colloidal and macromolecular constituents in surface waters. $\mathrm{PhD}$ (Thornton \& Boyden).

Millman, Anthony Philip. 1953. Theory and practice of geochemical prospecting The results of investigation in the West of England and West Africa. PhD [MG] (Webb).

Montgomery, Robert. 1971. Secondary dispersion of molybdenum and associated elements in the tropical rain forest environment of Guyana. $\mathrm{PhD}$ (Bradshaw).

Moon, Charles John. 1983. Factors controlling the surficial dispersion of arsenic, antimony, bismuth and selenium from surface deposits in the British Isles. $\mathrm{PhD}$ (Hale).

Moorby, Stuart Anthony. 1979. The geochemistry and mineralogy of some ferromanganese oxides and associated deposits from the Indian and Atlantic Oceans. $\mathrm{PhD}$ (Cronan).

Morgan-Jones, Martin. 1983. The natural bydrogeochemistry of the Lower Greensand of Hampshire and Surrey and its relationship to pollution: particularly from waste disposal activities. $\mathrm{PhD}$ [external] (Thornton).

Morris, Elizabeth Bronwen. 1978. The leaching of heavy metals from mine spoil into a river system. MSc [ET] (Thornton).

Ng, Chun Yeong. 1982. Geochemical applications in Hong Kong. MSc [ET] (Thornton \& W. W.-S. Yim).

Nicolls, Oliver Warburton. 1964. Geochemical dispersion from base metal deposits, Queensland, Australia. PhD (Webb, Tooms \& James).

Nutter, Alexander Henry. 1970. The origin and distribution of phosphate in marine sediments from the Moroccan and Portuguese continental margins. DIC (Tooms).

OAKES, BARRIE William. 1984. Vapour geochemical pathfinder for oxidising sulphide mineralization beneath exotic overburden. $\mathrm{PhD}$ (Hale).

Odada, Eric Elizaphans Onyango. 1987. Geochemical investigations on sediments from the Romanche Fracture Zone, equatorial Africa. $\mathrm{PhD}$ (Cronan).

Ong, Pablito Moslares. 1966. Geochemical investigation in Mount's Bay, Cornwall. $\mathrm{PhD}$ (Webb, Tooms \& Nichol).

Pahlavanpour, Behrooz. 1979. Plasma emission spectrometry for determining germanium, tin, arsenic, antimony, bismuth, selenium and tellurium in geochemical samples. PhD (Thompson).

Park, Jong Nam. 1983. Pattern recognition techniques for integration of geophysics, remote sensing, geochemistry and geology. $\mathrm{PhD}$ (Dr. D. Cowan [Geophysics] \& Howarth).

Peters, Ronald George. 1974. Secondary dispersion of sulphur from sulphide deposits in the Notre Dame Bay area, Newfoundland. PhD (Meyer).

Philobbos, Емad Ramzy. 1975. Geochemical and mineralogical studies on some phosphate sediments from Egypt. DIC (P.R. Bush; G).

Provan, Donald Malcolm Jamieson. 1965. An investigation of the factors governing the distribution of savanna plant communities in northern Australia with particular reference to geology and bedrock mineralization. $\mathrm{PhD}$ [Birmingham] (Dr. M. M. Cole [Bedford College], Webb \& Tooms).

Ramsey, Michael Henry. 1986. Improved performance of inductively coupled plasma atomic emission spectrometry in geochemical analysis. $\mathrm{PhD}$ (Thompson).

Ranasinghe, Vernon Victor Clement. 1984. The development of radiative neutron capture techniques for in-situ elemental analysis of the sea-bed. $\mathrm{PhD}$ (Cronan \& Dr. G. C. Clayton [Harwell]).

Reynolds, BRIAN. 1981. Geochemical studies on heavy metals in waters and sediments in Minsterly Brook, Shropshire, and the River Ecclesbourne, Derbyshire. PhD (Thornton \& Thorne).

Rubio Alvarez, Alberto. 1967. Geochemical prospecting studies in Flintshire; and a geophysical survey of the Perran iron lode, Cornwall. DIC [MG] (Nichol).

Rugheim, Моhammed el Hassan. 1970. Preliminary study of regional metal variations in Red Sea sediments related to hot brine occurrences. DIC (Tooms).

Russell, Keith James. 1988. Soil ingestion by sheep in England and Wales and its contribution to the dietary intake of trace elements. $\mathrm{PhD}$ (Thornton).

Sakellariadou, Fani. 1987. Geochemistry of nearshore sediments from the North Aegean Sea, Greece. PhD (Cronan \& Dr. P. Bush [G]). 
Sanders, Lesley Jean. 1977. The combined use of soil survey and geochemical reconnaissance data to study the distribution of trace elements in soils. $\mathrm{PhD}$ (Thornton).

Schiefler, Donald. 1967. Some aspects of the regional geochemistry of the Lunga Basin area, Zambia. PhD (Tooms \& Nichol).

Senaratne, Atula. 1982. Geochemical cycling of thallium in the environment. MSc [ET] (Dr. J. N. B. Bell; ET).

Sey, Solomon Kwesi. 1981. Factors affecting trace metal distribution in stream sediments in selected areas of base metal mineralization in Lancashire and Cornwall. MPhil (Hale).

Shearme, Sarah. 1982. The geochemistry of sediments from the Atlantic and Pacific Oceans. $\mathrm{PhD}$ (Cronan).

Sims, ANDREw. 1982. Geochemical prospecting in the search for metalliferous ore deposits in hot arid terrain. MSc [MG] (?).

Skirrow, Russell. 1983. A geochemical study of bydrothermal and associated sediments from the Eastern Pacific spreading centres. $\mathrm{PhD}$ (Cronan)

Smith, Christopher Arnold. 1983. The distribution of selenium in some soils developed on Silurian, Carboniferous and Cretaceous systems in England and Wales. $\mathrm{PhD}$ (Thornton).

Smith, Peter Adrian. 1979. Geochemical investigations of Recent sediments from the Aegean Sea. PhD (Cronan).

StagG, Ralph Nicholas. 1977. Geochemical prospecting in Malawi. MSc [MG] (Howarth).

Stanton, Ronald ERnest. 1959. A field method for the determination of antimony in soils. DIC (?Dr. A.J.E. Welch [Chemistry]).

Stern, John EDward. 1959, A statistical problem in geochemical prospecting. MSc [S] (Dr. T. Barnard [Mathematics] \& Tooms).

Summerhayes, Colin Peter. 1971. Phosphate deposits on the north west African continental shelf and slope. $\mathrm{PhD}$ (Tooms).

Swarbrick, Zelda Anne. 1980. The distribution of cadmium and associated elements within selected profiles at Shipham, Somerset. MSc [ET] (Thornton).

Tavora, Flávio Juarez. 1987. Lithogeochemistry and surficial redistribution of arsenic, antimony, bismuth, selenium and tellurium associated with mineral deposits in sub-tropical areas of Brazil. $\mathrm{PhD}$ (Hale).

TAYlor, Dennis. 1968. The interpretation of lead-rinc stream sediment anomalies related to contamination and mineralization in the United Kingdom. $\mathrm{PhD}$ (Nichol \& Webb).

Thomson, IAN. 1971. Regional geochemical studies of black shale facies with particular reference to trace element disorders in animals. $\mathrm{PhD}$ (Thornton \& Webb).

ThORNTON, IAIN. 1968. The application of regional geochemical reconnaissance to agricultural problems. $\mathrm{PhD}$ (Webb).

Tillson, John William. 1982. MINEX - A computer model to teach mineral exploration using controlled requirement specification (CORE). MSc [CS] (Prof. S.J. Goldsack; CS)

Tooms, John Somerville. 1955. Geochemical dispersion related to copper mineralization in Northern Rhodesia. PhD (Webb).

Turner, Mark ST.John. 1980. A comparative study of multiple regression technique. in geochemistry. MSc [MG] (Howarth).

Turner, Mark ST.John. 1987. Statistical analysis of geochemical data illustrated by reference to the Dalradian of N[orth]-E[ast] Scotland. $\mathrm{PhD}$ (Howarth \& Hale).

Urquidi-Barrau, Jorge] Fernando. 1973. Regional geochemical variations related to base metal mineralization in Wales. $\mathrm{PhD}$ (Meyer).

Varnavas, Soterios Petrou. 1979. Geochemical investigations on sediments from the Eastern Pacific. PhD (Cronan).

Venugopal, Kallat. 1952. Trace elements in cassiterite and stannite. PhD [MG] (Webb).

Verlaan, Philopmeme. 2003. Environmental controls on marine ferromanganese oxide behaviour in the Central South Pacific. PhD (Cronan).

Viewing, KeIth Alan. 1963. Regional geochemical patterns related to mineralization in central Sierra Leone, Nichol. PhD (Tooms \& Webb).

Walker, John Leiper. 1964. Primary geochemical dispersion in relation to the mineralization at Broken Hill, New South Wales. PhD (Webb).

Walker, Peter Bartlett. 1960. A study of the secondary dispersion of copper and chromium from mineral deposits in North Borneo. MSc (Webb \& Tooms).

Watling, Helen Ruth. 1975. Some aspects of trace element analysis of river and estuarine sediments and waters. DIC (Thornton).

Watling, Roger John. 1972. Mercury and associated trace elements in the primary environment, Keele prospect, County Longford, Ireland. PhD (Meyer).

WatTs, John Trevor. 1960. The secondary dispersion of niobium from pyrochlore carbonatites in the Feira District, Northern Rhodesia. PhD (Webb \& Tooms).

Wheatley, Michael Robert. 1984. The laser-ICP microprobe and other techniques applied to the study of pathfinder elements in fluvial systems. $\mathrm{PhD}$ (Hale).

Whiting, Carole. 1978. A study of metal concentrations in the River Hale, Cornwall. MSc. [ET] (Thornton).

Wighan, Helen. 1978. Heavy metal uptake by different plant species in an area of past metalliferous mining and smelting. MSc [ET] (Thornton).
Wilding, Ian George Proctor. 1966. Investigation of the secondary dispersion of nickel in Rhodesia and Zambia. PhD (Tooms).

Williams, Carolyn. 1970. Biogeochemical factors influencing plant uptake of molybdenum and selenium. MPhil (Thornton \& Webb).

Wood, Geoffrey ArThur. 1958. Studies on rapid analytical methods [for Sn and Sb] for use in geochemical prospecting. PhD (Dr. A.J.E. Welch [Chemistry] \& Webb).

Wood, Pauline. 1975. Regional geochemical studies in relation to agriculture in areas underlain by sandstones. $\mathrm{PhD}$ (Thornton \& Alloway).

Wraith, Dianne Elizabeth. 1982. The natural distribution of some Group Va and Vla elements as applied to mineral exploration. $\mathrm{PhD}$ (Hale).

YIM, Wyss WAI-SHu. 1974. Some aspects of the geochemistry of tin and other elements in sediments off north Cornwall. MPhil (Cronan).

Young, Robert Douglas. 1971. The interpretation of regional geochemical patterns in Northern Ireland. PhD (Lowenstein).

Zhou, Jiaxin. 1985. Geochemistry of Kimelford intrusives, West Scotland, in relation to the Caledonian orogeny. PhD (Howarth \& Prof. J.V. Watson [Geology]).

Zohar, Eliahu. 1965. The application of geochemical methods to prospecting for copper and arsenical-gold deposits in Guadalcanal, British Solomon Islands. MSc (James \& Tooms).

\section{Appendix 4. GPRC/AGRG staff members}

Analysts

Campain, Richard Phillips, 1969-85; Crundwell, Miss Norah Jane, 1954-55; Denison, Miss B.A., 1959-60; Hall, Miss R.A., ?1959; Read [née Symmonds], Mrs Kyrene, 1956-57; Wood, Geoffrey Arthur, 1954-57.

\section{Analytical Experimental Officer}

Clavering, Miss Bonamy Jane, 1969; Cole, Mrs Anna Georgina, 1965-67; Doyle, Alban, 1969-88; Eldred, Brian David, 1963; Forster, Alan, 1967-70; Forward, Trevor John, 1963-65; Guise, Philip George, 1969-72; Harman, Miss Barbara Louise Moira, 1965; Harris, Graham Jack Seymour, 1969-70; Lewis, Miss Wendy Elaine, 1960-63; Sheikh, Gulham Rasool, 1970-72; Stott, Michael A., 1969-72; Thomas, Clifford Fitzroy Macleod, 1967-72; Viewing [née Bierling], Mrs Frouwka, 1959-62; Williams, David Edward Gerrard, 1963-65.

\section{[Analytical] Research Officer}

Lam Shang Leen, K.C.Y. 1969-72; Wood, Dr. Shirley Janet, 1977-79.

\section{Academic staff}

Barringer, Prof. Anthony R., Visiting Prof., 1965-84; Boyle, Dr. Daniel Robert (1948-2000), 1971-76; Bradshaw, Dr. Peter Martin Devenish, 1965-69; Cronan, Prof. David Spencer, 1973-; Culbard, Dr. Elizabeth Brandon, 1980-86; Hale, Dr. Martin, 1976-83; Assistant Director, Geology Department 1984-90; Howarth, Dr. Richard John, 1968-85; Lowenstein, Dr. Peter Leslie, 1969-73; Meyer, Dr. William Timothy Wakeford, 1969-74; Nichol, Dr. Ian, 1961-69; Ramsey, Dr. Michael Henry, 1979-99; Thompson, Dr. Michael, 1969-87; Thornton, Prof. Iain, 1964-74; Asst. Head AGRG, 1974-79; Head, 1979-88; Director, Environmental Geochemistry Research Group, 1988-; Chairman, IC Centre for Environmental Technology 1986-90; Director, Global Environmental Research Centre 1990-94; Tooms, Dr. John Somerville, 195572; Webb, Prof. John Stuart (1920-2007), Lecturer [Mining Geology] 1947-55; Director GPRC/AGRG 1954-79; Sr. Research Fellow, 1979-88.

\section{Research Assistant}

Abrahams, Peter W., 1980-83; Bicknell, Mrs Jill Valerie, 1961_ 68; Brebner, Miss Jocelyn, 1985-86; Brereton, Miss Dorothy Ann, 1971-72; Cole, Tomas, 1983-87; Coles, Barry J, 1981-; Elderfield, Henry ("Harry"), 1968-69; Fielder, Miss Nicola A., 
1979-80; Gilbert, Miss Margaret A. ("Peggy") (1928-96), 1953-57; Goulter, John Edward, 1975-76; Halcrow, William, 1971-72; Henderson-Hamilton, Leslie James Campbell, 196165; Higgo, Miss Jennifer Joan Wynne, (Chemistry), 1981-87; Higgs, J, 1981-82; Hodkinson, Richard A., 1986-96; Horowitz, Arthur Joseph, 1971-74; Hunt, Andrew, 1986-89; Jones, David John William, Programmer analyst, 1983-84; Jordan, William James, 1971-73; Jorisi, E, 1978-83; Kerbyson, John Donald, 1957-60; Lovell, John Stanley, 1974-79; Lowry, Dr. Richard K., 1979-81; Mather, Alfred Lewis, 1958-60; McDonald [Mrs. Hardwick from 1967], Mrs Alison Jean, 1957-67; Moon, Charles J, 1980-82; Moorby, Dr. Stewart Anthony, 1979-86; Moorcroft, J. Stephen, 1979-83; Oakes, Barry W., 1980-83; Pahlavanpour, Dr. Behrooz, 1979-82; Poynter, Miss Daphne Ann, 1959-61; Rother, Dr. John A., (joint w. Botany), 1977-80; Sarkar, Dr. Shoudrop Lai, (Metallurgy), 1971-72, 1979; Shearme [later Mrs. Colley], Miss Sarah, 1980-81; Steward, Miss Angela Mary Carr, 1969-73; Summerhayes, Dr. Colin Peter, 1967-70; Thomas, Miss Rosemary Grace, 1960-61; Thompson, Anthony John, EO; Sr AT, 1962-77; Thoresby, Miss Pandora A., 1973-76; van Dorst, Miss Sheila Helena, 1984-87; Vivian, Christopher Martin Grose, 1975-76; Walton, Steven Jeremy, 1973-79; Watling, John, ?1971-73; Watt, John Michael, 197986; Wheatley, Michael, 1979-85.

\section{Research Fellow}

Alloway, Dr. Brian John, 1969-75; Aston, Simon Robert, 1972-74; Boyden, Dr. Charles Richard (1945-79), 1972-75;
Foster, John Robert, 1965-69; James, Dr. Clifford Henry (1931-2003), 1961-64; Kinniburgh, Dr. David George, 1975-78; Leggo, Michael David, Academic visitor, 1968-69; Newman, Ernest James, 1966-68; Stanton, Ronald Ernest (1919-79), 1956-68.

\section{Technician/technical assistant}

Ahmad, Answar, 1969-87; Ahmad, M.A., 1969-96; Auld, Miss Heather A., 1974-78; Banerjee, Mrs Eva K., 1965-92; Brooks, Miss Karen, 1979-80; Clemens, Mrs Maeve Jill, 1969-73; Cooper, J.B., 1977-78; Downes, Leslie, 1967-73; Forman, T., 1964-65; Fortey, John Edward, 1973-77; Gay, Miss Carol E.F., 1976-83; Harper, Martin, 1982-83; Heeley, Ms Judy Lynne, 1980-88; Hin, Mrs Ella Ng Chieng, 1968-71; Holden, Miss J. E., 1963-65; Howell, Miss Vanessa J., 1980; Johnson, Christopher, 1979-80; Kalsi, Amarjit, 1980; Langston, Miss P., 1958; Little, Miss Mary, ?1966-69; Murphy, Marion P., 1979-83; Muttiah, Miss Padma V., 1974-80; Nataraj, Mrs. Rebathi, 1971-74; Nicholls, Miss A., 1965; Robbins, Miss J. E., 1984-85; Rundle, Miss Stella Ann, 1976-79; Russell-Tanska (nee Sinclair-Gribble), Mrs Krystyna, 1982-83; Shariff, Mrs Farida, 1968-69; Theodoran, Theo, 1987-88; Thomas, Mrs Janet M., 1979-80 Turnbull, Miss Molly E., ?1969; Vernon, Miss Anne Primrose, 1977-79; Vine, Mrs Rose Violet, 1956-77; Williams, R.O., 1972-77. 